\title{
1 GM1a functions as a coreceptor/ attachment factor for Dengue 2 virus during infection in mammalian systems
}

\section{GM1a functions as a coreceptor/ attachment factor for Dengue}

6 Sarala Neomi Tantirimudalige ${ }^{1,3, \# a}$, Palur Venkata Raghuvamsi ${ }^{1,4}$, Jonathan Chua Wei Bao ${ }^{1}$, 7 Ganesh S. Anand ${ }^{1,5}$, and Thorsten Wohland ${ }^{1,2,3,6, *}$

${ }^{1}$ Department of Biological Sciences, National University of Singapore, 14 Science Drive 4, Singapore 117543, Singapore

112 Department of Chemistry, National University of Singapore, 14 Science Drive 4, Singapore 117543, Singapore

${ }^{3}$ Centre for Bioimaging Sciences, National University of Singapore, 14 Science Drive 4, Singapore 117557, Singapore

${ }^{4}$ Bioinformatics Institute (A*STAR), 30 Biopolis Street, \#07-01 Matrix, Singapore 138671, Singapore

5 The Pennsylvania State University Department of Chemistry, 202 South Frear Building,

${ }^{6}$ Lead Contact

\#a Current Address: Department of Chemistry, University of Colombo, 94 Kumaratunga 


\section{Abstract:}

Dengue virus (DENV) is a flavivirus causing an estimated 390 million infections per year around the world. Despite the immense global health and economic impact of this virus, its true receptor(s) for internalization into live cells has not yet been identified, and no successful antivirals or treatments have been isolated to this date. This study aims to improve our understanding of virus entry routs by exploring the sialic acid-based cell surface molecule GM1a and its role in DENV infection. The interaction of the virus with GM1a was studied using fluorescence correlation spectroscopy (FCS), fluorescence cross correlation spectroscopy (FCCS), imaging FCS (ImFCS) and amide hydrogen/deuterium exchange mass spectrometry (HDXMS), and the effect on infectivity and movement of the virus during infection was explored using plaque assays and fluorescence-based imaging and single particle tracking (SPT). GM1a was deemed to interact with DENV at domain I (DI) and domain II (DII) of the E protein of the protein coat at quaternary contacts of a fully assembled virus, leading to a ten-fold increase and seven-fold increase in infectivity for DENV1 and DENV2 in mammalian cell systems respectively. The interaction of virus with GM1a triggers a speeding up of virus movement on live cell surfaces, possibly resulting from a reduction in rigidity of cellular rafts during infection, and functions as a coreceptor/ attachment factor for DENV during infection in mammalian systems.

\section{Author Summary:}

Dengue virus (DENV) is a flavivirus causing an estimated 390 million infections per year around the world. Despite the immense global health and economic impact of this virus, no successful antivirals or treatments have been isolated to this date. This may be due to the 
incomplete understanding of the virus infection mechanism, including a lack of an identified 'true' receptor and entry related attachment factors or co-receptors responsible for internalization of the virus. This work focuses on the early infection stage of DENV1 and DENV2 strains, to identify how the virus moves on cell surfaces in its search for its receptors, and identifies the critical role of the sialic acid ganglioside GM1a during internalization of the virus.

\section{Introduction:}

Dengue virus (DENV) is a mosquito-borne enveloped virus, from the Flaviviridae family. It is transmitted from human to human by the bite of an infected mosquito (Aedes aegypti, and occasionally Ae. albopictus) with symptoms ranging from fever, muscle and joint pain (Dengue fever) to a more life-threatening haemorrhagic fever or shock syndrome, in both adults and children alike [1-3]. It has been estimated that there are as many as 390 million dengue infections per year, spread throughout 128 countries, of which 96 million manifest clinically with symptoms [4-6], posing a major global health impact.

DENV has four identified serotypes (DENV1, DENV2, DENV3, DENV4). It has a diameter close to $500 \AA$ with an outermost protein shell which is embedded in the host-derived lipid bilayer, which in turn encapsulates the $\sim 11 \mathrm{~kb}$ single stranded positive sense RNA genome which encodes 10 viral proteins, out of which 3 are structural (capsid (C), the pre-membrane or membrane (prM or M respectively) and the envelope (E) proteins) and 7 are non-structural (NS1, NS2a, NS2b, NS3, NS4a, NS4b and NS5) in function [1,4,7-9]. The outer most protein shell of mature DENV is made up of 180 copies of E and 180 copies of M proteins arranged in an icosahedral manner [4]. The E protein is the major antigenic structure on the surface of the virus and is involved in receptor and attachment factor binding [4,8,10-16]. Infectious DENV 
particles interact with attachment factors on the cell membrane, followed by movement along the cell surface in its search for its receptors and co-receptors, which internalize it into its host cell $[13-15,17,18]$.

Current research work and literature highlight a number of receptors/co-receptors/attachment factors involved in DENV internalization, with no definitive answer on what factors are truly the most critical for virus internalization. The adhesion molecule of dendritic cells DC-SIGN, ER chaperonin GRP-78, the $37 / 67 \mathrm{kDa}$ high-affinity laminin receptor, heat shock proteins 70 and 90, glycosaminoglycans (GAGs) such as heparan sulfate (HS), heparan sulfate proteoglycans (HSPG) and lectins, TIM and TAM proteins, mannose receptor (MR) of macrophages, lipopolysaccharide (LPS) receptor CD14, glycosphingolipids (GSL), claudin-1, are a few among these explored receptors and attachment factors for DENV in mammalian cell systems $[1,12,26-28,14,19-25]$. Having a broad range of receptors and entry routes, DENV appears to possess the ability to infect many different types of cells, using many different mechanisms, and may use entry routes more ubiquitous in nature and reflective of the diversity in cell surface composition.

In this work we focus on the ganglioside GM1a and describe its involvement in DENV infection in mammalian cell systems. GM1a is a glycosphingolipid, with a glycan part and lipid portion which contributes to the glycocalyx and lipidome of cells, respectively. It possesses a terminal sialic acid moiety, which interacts with cargo such as Cholera Toxin B (CTxB), viruses and bacteria, in order to internalize them into cells [29-34]. Sialic acids of the ganglioside family, are ubiquitously found in most mammalian cells and are important for cell signalling, cell adhesion and many other cellular functions [35-41]. Mammalian cells have a dense glycocalyx, and more often than not, the first point of contact for any pathogen will be the glycan interaction points on cell surfaces, and more than half of all known mammalian 
viruses are reported to interact with glycans during internalization. The diversity of viruses that can interact with sialic acid moieties range from membranous to non-membranous, those that have capsids, to those that do not, and both virus types with RNA encoded or DNA encoded genomes [42-48].

One such virus is the Influenza A virus (IAV) (Orthomyxoviridae), which shows interaction with sialic acid moieties on host cell surface during infection [44,46,48-51]. The virus surface is decorated with two surface glycoproteins, hemagglutinin $(\mathrm{H} / \mathrm{HA})$ and neuraminidase (N/NA). The hemagglutinin is responsible for interacting with the sialic acid moiety (Neu5Ac) on cell surfaces, and initiates viral internalization, possibly with the help of another more proteinaceous receptor [52-55]. Paramyxovirus (Paramyxoviridae) binds sialic acid residues in a similar fashion to IAV, where the virus surface hemagglutinin-neuraminidase (HN) glycoprotein binds to sialic acid on host cells, mediating virus internalization [56]. Newcastle Disease (NDV), Sendai, mumps, and parainfluenza viruses are reported to recognize glycans with the terminal NeuAca2-3Gal linkage [46,57]. Simian virus 40 (SV40) is reported to be highly specific for GM1 binding, where the capsid protein, VP1, forms a complex with the carbohydrate portion of GM1, confirmed by crystallography studies [46,51,58-60]. Coronavirus (Coronaviridae) surfaces hold two glycoproteins, a spike protein and hemagglutinin-esterase, which can both interact with glycans as primary/co-receptors or as attachment factors. Feline coronavirus (FCoV), Transmissible gastroenteritis virus (TGEV), Porcine Epidemic Diarrhoea (PED), have all been reported to bind sialic acid host at cell receptors (NeuAc/NeuGc ) via the spike protein as a secondary receptor [61]. The spike on Human Respiratory Coronavirus (OC43) and Human Coronavirus (HKU1), is reported to interact with NeuAc as a primary receptor, while Middle East respiratory syndrome (MERS) binds sialic acid with a preference for an a2,3-link [46,51,62-64]. Picornaviruseses (Picornaviridae) Coxsackie A24, human enterovirus 68 and Murine encephalomyocarditis 
virus, all bind sialic acid receptors at the NeuAca2-6Gal and/or NeuAca2-3Gal sites on Nglycans [46,65-67]. It has been recently shown that Sialic acid-containing glycolipids including GM1 mediates binding and viral entry of SARS-CoV-2 [68]. Various viruses in the families of Polyomavirus (Polyomaviridae), Parvovirus (Parvoviridae), Rotavirus and Orthoreovirus (Reoviridae), Caliciviruses (Caliciviridae), and Mammarena viruses in the family of Arenaviruses (Arenaviridae), have all been shown to interact with sialic acid containing glycans during cellular infection [44,46,69-74], making sialic acid containing glycan receptors a widely utilized entry route by many types of viruses.

In this work, the interaction of DENV1 (PVP 159) and DENV2 (NGC strain) with the sialic acid ganglioside GM1a was explored and confirmed by Fluorescence Cross Correlation Spectroscopy (FCCS), Fluorescence colocalization studies, Fluorescence Single Particle Tracking (Fluorescence SPT), and Imaging Fluorescence Correlation Spectroscopy (ImFCS). The interaction site of GM1a with DENV was mapped by amide hydrogen/deuterium exchange mass spectrometry (HDXMS). The impact on infectivity of this interaction of DENV1 and DENV2 with GM1a was tested by plaque assays, and it is shown that both DENV1 and DENV2 show increased infectivity in the presence of GMla. Taken together our results show that, DENV1 and DENV2, interact with GM1a on mammalian cells, resulting in increased infectivity of the virus, and functions as an attachment factor/receptor/co-receptor during virus internalization.

\section{Results}

\section{Interaction of Dengue virus with surface GM1a on live mammalian cells}

The involvement of GM1a during DENV infection was probed using colocalization studies and quasi pulsed interleaved fluorescence cross-correlation spectroscopy (qPIE-FCCS) [75] in 
live Vero cells. Colocalization studies and time-lapse imaging carried out on a confocal microscope showed that DENV1 and DENV2 particles each colocalized and moved together with GM1a-Bodipy on live cell surfaces (S2 Fig and S1 Table). For a more direct measurement of interactions, qPIE-FCCS experiments on the confocal microscope were conducted between GM1a labelled with Bodipy FL (GM1a-Bodipy), and DENV labelled with Alexa Fluor 555 NHS (Fig 1). The degree of interaction in qPIE-FCCS was semi-quantitatively evaluated using the so-called $q$-value, which is proportional to the interaction detected (see materials and methods section). As negative control we used DiIC18(3) and GM1a-Bodipy, two lipids not expected to interact as they partition into liquid disordered or liquid ordered regions, respectively. As positive control we used PMT-mEGFP-mApple, a plasma membrane targeting sequence where both red and green fluorophores are linked to each other and thus should provide a maximum of cross-correlation achievable with the setup [76]. While qPIE-FCCS negative and positive controls showed $q$-values of $0.03 \pm 0.01(\operatorname{Avg} \pm \mathrm{SEM}$; cells $=6)$ and $0.45 \pm 0.01(\operatorname{Avg} \pm$ SEM; cells $=10)$, respectively, DENV1 and DENV2 showed intermediate $q$ values of $0.15 \pm 0.02(\operatorname{Avg} \pm \mathrm{SEM}$; cells $=19)$ and $0.21 \pm 0.02(\operatorname{Avg} \pm \mathrm{SEM}$; cells $=58)$, indicating clear interactions. As a further control we measured the interaction of GM1a and CTxB, a known GM1a binding protein [29,30], which yielded a $q$ value of $0.25 \pm 0.04$ (Avg \pm SEM; cells $=9)$.

\section{Mapping the binding hotspots of GM1a on DENV E-protein}

Colocalization of GM1a glycosphingolipid with DENV2 particles was confirmed by FCCS. We performed HDX-MS on free DENV2 and DENV2 in the presence GM1a sugar moiety to identify the binding hotspot of GM1a on the DENV viral surface. 36 pepsin proteolyzed peptides were obtained with high signal to noise ratios and covering $63 \%$ of the E protein 
sequence. Here, we used high molar ratio GM1a sugar moiety to that of E protein dimer (125:

1) to achieve saturation in GM1a binding on viral surface. DENV2 using deuterium exchange difference plot. A deuterium exchange difference plot (Fig 2A) shows the difference in number of deuterons exchanged between DENV2:GM1a and free DENV2 at 1 min of deuterium labelling time for each pepsin digested peptide. In the presence of GM1a, peptide 40-57, 129-136 and 322-335 showed lower deuterium exchange (Fig 2A). Peptide 40-57 and 129-136 span the domain I (DI) and domain II (DII) of the E protein. Peptide 322-335 is localized at the five-fold symmetry axis of the virion (Fig 2D). Previous reported crystal structures of the $\mathrm{E}$ protein complexed with carbohydrate molecule $\beta$-octyl glucopyranoside ( $\beta O G$ pocket) (PDB: 1OKE) shows a similar binding site for sugar molecules spanning DI and DII [77]. We also performed control HDX-MS experiments to map interactions of GM1a with recombinant DENV2 E protein/soluble E protein (sE protein). We observed no changes in deuterium exchange in the presence of GM1a (S4 Fig). This indicates that GM1a requires quaternary contacts of a fully assembled virus to bind to the surface. Furthermore, DENV1 and DENV2 both show a $\sim 67 \%$ sequence similarity of the E protein (S5 Fig), therefore it can be expected that DENV1 may also bind GM1a in a similar fashion to that of DENV2.

It is important to note that the $\sim 37 \%$ E protein regions lacking coverage in our experiments that span domain II (peptide 59-92) and domain I/domain III (peptide 280-317) are surface exposed and form quaternary contacts in the virion. Due to the lack of deuterium exchange measurements, we cannot describe the role of these regions in binding to GM1a. 
The biological significance of the proximity of GM1a and DENV observed by qPIE-FCCS and colocalization studies was further investigated on live BHK21 mammalian cells by conducting plaque assays. The infectivity levels were compared for untreated cells, GM1a depleted cells and GM1a enriched cells (Fig 3). GM1a depletion was achieved by D-PDMP treatment, while GM1a enrichment was by BSA loading (see Materials and Methods). DENV1 and DENV2 both show a similar trend in infectivity with relation to GM1a on cell surfaces, with a significant increase in infectivity seen for the GM1a enriched cells as compared to the GM1a depleted cells. DENV1 shows an increase in infectivity in GM1a enriched cells with an average value of $6.0 \times 10^{7} \mathrm{PFU} / \mathrm{ml}$, as compared to $5.4 \times 10^{6} \mathrm{PFU} / \mathrm{ml}$ for D-PDMP treated (GM1a depleted) cells, in three repeat experiments (Fig 3A). While DENV2 shows an increase in infectivity in cells enriched with GM1a, with an average value of $1.3 \times 10^{15} \mathrm{PFU} / \mathrm{ml}$ versus a value of $8.5 \times 10^{8} \mathrm{PFU} / \mathrm{ml}$ in GM1a depleted plates, for three repeat experiments (Fig 3B). The three trials in both DENV1 and DENV2 show a similar trend of increased infectivity in GM1a enriched cells, as compared to the GM1a depleted and untreated cells. This indicates that GM1a significantly increases infectivity of DENV, but is not the only route of entry for the virus, where in the absence of GM1a, the infection is not completely abolished, and the virus internalizes by other routes.

Interaction of GM1a with DENV1 and 2 triggers increased diffusion of virus on the cell surface

The interaction of DENV with GM1a was further studied using fluorescence based SPT, where the movement of DENV1 and DENV2 was observed in GM1a depleted and GM1a enriched (cells were treated with D-PDMP and subsequently enriched with GM1a) live Vero cells. The diffusion coefficient of both DENV1 and DENV2 shows an increase in GM1a enriched as 
opposed GM1a depleted cells (Fig 4, S8 Fig). The Diffusion coefficients of DENV1 and DENV2 on cell membranes of GM1a depleted cells show similarity to each other at $0.005 \pm 0.001 \mu \mathrm{m}^{2} / \mathrm{s}(\operatorname{Avg} \pm \mathrm{SEM} ;$ tracks $=260)$ and $0.005 \pm 0.001 \mu \mathrm{m}^{2} / \mathrm{s}(\operatorname{Avg} \pm \mathrm{SEM} ;$ tracks $=$ 487), respectively. In GM1a enriched cells, DENV1 (colocalized with GM1a) showed a diffusion coefficient of $0.010 \pm 0.002 \mu \mathrm{m}^{2} / \mathrm{s}(\mathrm{Avg} \pm \mathrm{SEM}$; tracks $=86)$, which is an increase in D from its movement in GM1 a depleted cells $(\mathrm{P}=0.0676$, difference is not statistically significant at $95 \%$ confidence interval), while DENV2 showed a similar trend with an increase to $0.015 \pm 0.002 \mu \mathrm{m}^{2} / \mathrm{s}(\mathrm{Avg} \pm \mathrm{SEM}$; tracks $=417)$ in GM1a enriched cells as compared to trajectories in GM1a depleted cells $(\mathrm{P}<0.0001$, difference is statistically significant at 95\% confidence interval) (Fig 4). This indicates that DENV1 and DENV2 movements are influenced by the association with GM1a.

The changes in diffusion of DENV on cell membranes might also indicate a change in the mode of diffusion. GM1a is located in lipid rafts of mammalian cell membranes, and any changes in organization may influence the diffusion of cargo associated with GM1a on cell membranes $[78,79]$. For this purpose, we performed ImFCS measurements on live Vero cells transfected with the raft marker GFP-GPI and pre-enriched with GM1a, to compare changes that occur before and after overlay of DENV. ImFCS is capable of determining the diffusion mode of cell membrane components [80]. The GFP-GPI $\tau_{0}$ values reduced from $0.53 \pm 0.30 \mathrm{~s}$ before (cells $=6$, with 3 sets of $21 \times 21$ pixel areas per cell for ImFCS) to $0.34 \pm 0.15 \mathrm{~s}$ after DENV1 addition $(\mathrm{P}=0.0131$, difference is statistically significant at $95 \%$ confidence interval) (Fig 5B). While in the case of DENV2, a similar trend was observed where $\tau_{0}$ showed a reduction from $0.68 \pm$ $0.31 \mathrm{~s}$ to $0.51 \pm 0.30 \mathrm{~s}$ (cells $=5$, with 3 sets of $21 \mathrm{x} 21$ pixel areas per cell for ImFCS) in the absence and presence of DENV2 respectively $(\mathrm{P}=0.1382$, difference not statistically significant.) (Fig 5). This reduction in $\tau_{0}$ for GFP-GPI raft marker indicates a change in the probe diffusion mode from transient domain confined to a freer diffusion, which in turn 
indicates a change of the raft organization tending towards a slightly less rigid organization allowing more freedom of movement for lipids and embedded proteins. This reduction in rigidity could be attributed to the faster movement of both DENV1 and DENV2 when colocalized with GM1a, as observed in 2D SPT trajectory data. These results were compared with ImFCS studies before and after addition of CTxB (labelled with Alexaflour555) under the same conditions. In the case of $\mathrm{CTxB}$, however, there was an inversion in the GFP-GPI $\tau_{0}$ value, where there was an increase in $\tau_{0}$ from $0.58 \pm 0.50 \mathrm{~s}$ to $1.44 \pm 0.75 \mathrm{~s}($ cells $=4$, with 3 sets of $21 \times 21$ pixel areas per cell for ImFCS) before addition of CTxB and after the addition of $\mathrm{CTxB}(\mathrm{P}=0.0032$, difference is statistically significant.) (Fig 5). This indicates a possible increase in the rigidity of the lipid raft after $\mathrm{CTxB}$ binding. $\mathrm{CTxB}$ is known to bind multiple GM1a receptors (up to five) and is reported to stabilize raft domains via a lipid cross-linking mechanism $[81,82]$, leading to an increased rigidity to the lipid raft they reside on, which could lead to the GFP-GPI probe to experience a more rigid raft environment, leading to the increase in $\tau_{0}$. Interestingly however, in the case of DENV1 and DENV2, the lipid raft region tends toward decreasing rigidity, indicating a difference in the way the virus binds to GM1a as compared to that of $\mathrm{CTxB}$. The integrity of the plasma membrane after D-PDMP treatment and GM1a enrichment was checked by conducting FCS studies on GFP-GPI raft marker and DiIC18 liquid disordered marker, and it was observed that the diffusion coefficient of GFPGPI was at $0.67 \pm 0.49 \mu \mathrm{m}^{2} / \mathrm{s}($ cells $/$ curves $=7 / 19)$ and $0.75 \pm 0.32 \mu \mathrm{m}^{2} / \mathrm{s}($ cells $/$ curves $=$ 10/29) for untreated and D-PDMP treated Vero cells respectively, indicating that no changes to membrane raft regions occurred due to D-PDMP treatment (S9 Fig). Similarly, FCS of DiIC18(3) liquid disordered marker was conducted on both non-treated and D-PDMP treated Vero cells, and the diffusion coefficients were at $1.59 \pm 0.77 \mu \mathrm{m}^{2} / \mathrm{s}($ cells/curves $=6 / 11)$ and 
disordered regions also do not undergo any organization changes due to the treatment with DPDMP (S10 Fig).

\section{Discussion:}

DENV is known to enter mammalian cells using many different entry mechanisms, while utilizing many different types of receptors/co-receptors/attachment factors. The range of receptors and cells DENV is reported to infect, hints towards a more ubiquitous form of entry which is available on many cells. Any virus when approaching the cell surface must find its way to these entry points for successful access into the host system. Mammalian cell membrane consists of a mosaic of lipids and proteins which are known to form liquid ordered (rafts) and liquid disordered regions, and encompass various receptors both proteinaceous and others. The cell surface is decorated with sugar antennas which form the glycocalyx, extending outward towards the extracellular environment, to regions beyond the reach of cellular receptors, which forms the first barrier that any virus will encounter as it approaches the cell surface. Thus, it is important to note that any virus that internalizes into a living cell must travel past this first barrier, and it is biologically important to identify how sugar-based molecules are involved in the virus infection process.

In this work we focus on GM1a, which is a glycosphingolipid with a sialic acid-based sugar found ubiquitously on mammalian cell surfaces, with its sugar moiety located within the glycocalyx. Sialic acid-based sugars have been widely reported to be involved in internalizing many different types of viruses, including Influenza A and SARS-Cov-2. We explore the involvement of GM1a and its sialic acid moiety in DENV internalization by using real-time fluorescence microscopy techniques. GM1a labelled with bodipy colocalizes with both DENV1 and DENV2 on live Vero cell systems, and moves along the cell surface together, 
indicating binding of the viral cargo onto the GM1a moiety. This binding of DENV with GM1a is further confirmed by our FCCS results, where a positive $q$ value of $0.15 \pm 0.02$ and $0.21 \pm 0.02$ for DENV1 and DENV2 was observed. The biological significance of this binding of DENV with GM1a and its effect on infectivity of DENV1 and DENV2 was then explored by plaque assay, where it was evident that the presence of GM1a on mammalian cell surfaces significantly increases the infectivity of both DENV1 and DENV2 as compared to the GM1a depleted states. The association of DENV with GM1a shows a significant effect on the infection process of DENV, and being a ubiquitously available molecule on mammalian cell surfaces, it acts as a more universal interacting partner during virus internalization.

The sialic acid receptor GM1a is reported to bind CTxB protein cargo via the two terminal sugars (galactose and sialic acid) on the receptor, in the form of a two fingered grip, involving ionic interactions between the positively charged protein cargo and the negatively charged sialic acids, along with solvent-mediated hydrogen bonding [29]. Haemagglutinin on influenza viruses binds sialic acid receptors (commonly $\mathrm{N}$-acetyl neuraminic acid (Neu5Ac)) with Avian influenza viruses preferentially binding to $\alpha 2,3$-linked sialic acid, and human-adapted viruses binding to $\alpha 2,6$-linked sialic acid moieties [44].

In this work, the binding of DENV2 virus to the sugar moiety of GM1a occurs in the regions spanning across domain I (DI) and domain II (DII) of E protein, while recombinant DENV2 E protein alone does not significantly bind GM1a under our experimental conditions. This indicates that GM1a requires quaternary contacts of a fully assembled virus to bind to the surface. The binding of GM1a sialic acid moiety may follow ionic interactions between the negatively charged sugar, and the more positively charged virus surface E protein, along with possible solvent mediated $\mathrm{H}$-bonding to further stabilize the interaction. The E proteins of both DENV1 and DENV2 show sequence similarity of $\sim 67 \%$, indicating preservation of similarity 
of E protein arrangement of the two variants. Thus, DENV1 interaction with GM1a sialic acid may show a similar binding pattern to that of DENV2.

DENV1 and DENV2 once colocalized with GM1a on live cell surfaces, shows movement along the cell membrane. Any cargo once attached to the attachment-factor/coreceptor undergoes movement along the cell surface, as it "surfs" and "tumbles" in search of the optimum orientation and supporting coreceptors and "true" receptors for its internalization. In this work, both DENV1 and DENV2 show an increase in movement speeds once it is colocalized with GM1a, as opposed to the GM1a depleted states, indicating that once attached to GM1a, the sialic acid receptor promotes faster movement of the virus on live cell surfaces. This increase in speed can allow the virus cargo to surf the cell surface more efficiently in search of its final "true" receptor. Once the true receptor is found, the virus will attain an immobile state and finally internalize. Thus, it can be interpreted that GM1a acts more as an attachment-factor or co-receptor for both DENV1 and DENV2, in assisting its internalization and infection process into live mammalian cells.

This increase in movement of DENV1 and DENV2 goes hand in hand with changes that undergo on the cell membrane organization. Once DENV associates with GM1a, there is an increase in fluidity of the membrane raft regions, indicated by the decrease in GFP-GPI raft marker $\tau_{0}$ value obtained by ImFCS. This indicates a change in the probe diffusion mode from transient domain confined to a freer diffusion, which in turn indicates a change of the raft organization tending towards a slightly less rigid organization allowing more freedom of movement for lipids and embedded proteins. This change in the lipid rafts possibly allow the DENV-GM1a complex to travel faster on the cell membrane surface. The interaction of DENV with GM1a, is thus different to that of $\mathrm{CTxB}$ binding to GM1a, as CTxB binding triggers increased cross linking between GM1a molecules inside the raft region, leading to increased 
rigidity. Thus, the binding of DENV with GM1a, does not appear to require cross-linking of GM1a.

GM1a may act as an important attachment-factor/coreceptor for DENV entry into mammalian cells, which support DENV movement to assist finding of the "true" receptors for virus internalization. GM1a is important in this search for the true receptor, as its absence clearly reduces the infectivity of both DENV1 and DENV2. Depletion of GM1a reduces, but does not abolish infection, and thus, GM1a is deemed to be one of many entry mechanisms into mammalian cells. The dynamics of DENV binding to GM1a need to be explored further, as the effect on the cell membrane during binding of virus to GM1a is an interesting phenomenon that is quite different to the normal way GM1a is known to participate in internalizing cargo such at CTxB. Further, the final receptor for DENV1 and DENV2 is not known as of now, and DENV into mammalian cells.

Materials and Methods:

Key Resources Table

\begin{tabular}{|l|l|l|}
\hline Chemical or resource & Source & Identifier \\
\hline $\begin{array}{l}\text { DENV2 New Guinea C } \\
\text { strain (NGC) }\end{array}$ & $\begin{array}{l}\text { The laboratory of } \\
\text { Michael Rossmann }\end{array}$ & \\
\hline DENV1 PVP 159 strain & $\begin{array}{l}\text { The laboratory of } \\
\text { Michael Rossmann }\end{array}$ & REC31680-100 \\
\hline $\begin{array}{l}\text { Dengue Virus Serotype 2 } \\
\text { Envelope Protein }\end{array}$ & $\begin{array}{l}\text { The Native Antigen } \\
\text { Company, UK }\end{array}$ & SH30237.01 \\
\hline HEPES (Hyclone) & $\begin{array}{l}\text { GE Healthcare life } \\
\text { sciences, UK }\end{array}$ & $\begin{array}{l}\text { Sigma-Aldrich, } \\
\text { Singapore }\end{array}$ \\
\hline NaCl & $\begin{array}{l}\text { Molecular Probes, Life } \\
\text { Technologies, USA }\end{array}$ & A37571 \\
\hline Alexaflour555 NHS Ester & & \\
\hline
\end{tabular}




\begin{tabular}{|c|c|c|}
\hline Dil'(DiIC18(5)-DS) & $\begin{array}{l}\text { Molecular Probes, Life } \\
\text { Technologies, USA }\end{array}$ & D12730 \\
\hline $\begin{array}{l}\text { 1,1'-Dioctadecyl-3,3,3',3'- } \\
\text { Tetramethylindocarbocyan } \\
\text { ine Perchlorate } \\
(\text { DiIC18(3)) }\end{array}$ & Invitrogen, Singapore & D282 \\
\hline EDTA & $\begin{array}{l}\text { Sigma-Aldrich, } \\
\text { Singapore }\end{array}$ & $60-00-4$ \\
\hline $\begin{array}{l}\text { bovine serum albumin } \\
\text { (BSA) }\end{array}$ & $\begin{array}{l}\text { Sigma-Aldrich, } \\
\text { Singapore }\end{array}$ & $9048-46-8$ \\
\hline $\mathrm{D}_{2} \mathrm{O}$ & $\begin{array}{l}\text { Cambridge Isotope } \\
\text { Laboratory Inc. }\end{array}$ & $7789-20-0$ \\
\hline $\mathrm{NaOH}$ & $\begin{array}{l}\text { Sigma-Aldrich, } \\
\text { Singapore }\end{array}$ & $1310-73-2$ \\
\hline $\mathrm{GnHCl}$ & $\begin{array}{l}\text { Sigma-Aldrich, } \\
\text { Singapore }\end{array}$ & $50-01-1$ \\
\hline $\begin{array}{l}\text { Tris(2-carboxyethyl) } \\
\text { phosphine-hydrochloride } \\
\text { (TCEP-HCl) }\end{array}$ & $\begin{array}{l}\text { Sigma-Aldrich, } \\
\text { Singapore }\end{array}$ & $51805-45-9$ \\
\hline titanium dioxide $\left(\mathrm{TiO}_{2}\right)$ & $\begin{array}{l}\text { Sigma-Aldrich, } \\
\text { Singapore }\end{array}$ & $13463-67-7$ \\
\hline $\begin{array}{l}\text { RPMI (Roswell Park } \\
\text { Memorial Institute) }\end{array}$ & $\begin{array}{l}\text { Sigma-Aldrich, } \\
\text { Singapore }\end{array}$ & SH30255.FS \\
\hline $\begin{array}{l}\text { C6/36 Aedes albopictus } \\
\text { mosquito cells }\end{array}$ & $\begin{array}{l}\text { American Type Culture } \\
\text { Collection (ATCC) }\end{array}$ & CRL-1660 \\
\hline $\begin{array}{l}\text { baby hamster kidney } \\
\text { fibroblast cells (BHK 21) }\end{array}$ & $\begin{array}{l}\text { American Type Culture } \\
\text { Collection (ATCC) }\end{array}$ & CCL-10 \\
\hline $\begin{array}{l}\text { Vero (African green } \\
\text { monkey kidney cells) }\end{array}$ & $\begin{array}{l}\text { American Type Culture } \\
\text { Collection (ATCC) }\end{array}$ & Vero-81 \\
\hline $\begin{array}{l}\text { PROTEIN LYNX } \\
\text { GLOBAL SERVER } \\
\text { version } 3.0\end{array}$ & Waters, USA & $\begin{array}{l}\text { http://www.waters.com/waters/e } \\
\text { n SG/ProteinLynx- } \\
\text { Global-SERVER }\end{array}$ \\
\hline $\begin{array}{l}\text { DYNAMX Ver. } 2.0 \\
\text { software }\end{array}$ & Waters, USA & $\frac{\text { http://www.waters.com/waters/li }}{\text { brary.htm?cid=511436\&lid= }}$ \\
\hline $\begin{array}{l}\text { D-PDMP }((+)-D-t h r e o-1- \\
\text { Phenyl-2-decanoylamino- } \\
\text { 3-morpholino-1-propanol } \\
\text { (hydrochloride) }\end{array}$ & Cayman Chemical, USA & 10178 \\
\hline $\begin{array}{l}\text { BODIPY FL C5- } \\
\text { Ganglioside GM1 }\end{array}$ & Invitrogen, Singapore & cat B13950 \\
\hline $\begin{array}{l}\text { MicroSpinTM S-200 HR } \\
\text { columns }\end{array}$ & $\begin{array}{l}\text { GE Healthcare, } \\
\text { Singapore }\end{array}$ & GE27-5120-01 \\
\hline Fetal bovine serum (FBS) & $\begin{array}{l}\text { Hyclone, GE Healthcare, } \\
\text { UK }\end{array}$ & SH30071.03HI \\
\hline Penicillin-Streptomycin & Gibco Life Technologies & Gibco $^{\mathrm{TM}} 15140122$ \\
\hline
\end{tabular}




\begin{tabular}{|l|l|l|}
\hline $\begin{array}{l}\text { 8-well chambered cover- } \\
\text { glass }\end{array}$ & $\begin{array}{l}\text { Thermo Scientific Nunc } \\
\text { Lab-Tek Chambered } \\
\text { coverglass }\end{array}$ & C7182-1CS \\
\hline HBSS & $\begin{array}{l}\text { HyClone Hank's 1X } \\
\text { Balanced Salt Solutions }\end{array}$ & SH30031.FS \\
\hline $\begin{array}{l}\text { Phenol red free RPMI } \\
\text { (with 25 } \mu \text { M HEPES) }\end{array}$ & $\begin{array}{l}\text { Gibco } \\
\text { RPMI 1640 Medium, no } \\
\text { phenol red }\end{array}$ & 11835030 \\
\hline $\begin{array}{l}\text { Ganglioside GM1 (Ovine- } \\
\text { Sodium salt) }\end{array}$ & $\begin{array}{l}\text { Avanti Polar Lipids, Inc., } \\
\text { Alabama }\end{array}$ & $\begin{array}{l}\text { CAS: 37758-47-7 SKU: } \\
860065 \text { P-5mg }\end{array}$ \\
\hline GFP-GPI & $\begin{array}{l}\text { kind gift of Dr. John } \\
\text { Dangerfield (Anovasia } \\
\text { Pte Ltd., Singapore) }\end{array}$ & \\
\hline $\begin{array}{l}\text { Electroporation buffer R } \\
\text { and E }\end{array}$ & $\begin{array}{l}\text { Invitrogen, Life } \\
\text { Technologies, Singapore }\end{array}$ & MPK10096 \\
\hline Neon transfection System & $\begin{array}{l}\text { Life Technologies, } \\
\text { Carlsbad, CA }\end{array}$ & MPK5000 \\
\hline Aquacide-II & Merck, Germany & $17851-M$ \\
\hline Crystal violet & $\begin{array}{l}\text { Sigma-Aldrich, } \\
\text { Singapore }\end{array}$ & C0775 \\
\hline Formaldihyde & $\begin{array}{l}\text { Sigma-Aldrich, } \\
\text { Singapore }\end{array}$ & 252549 \\
\hline Defatted BSA & $\begin{array}{l}\text { Sigma-Aldrich, } \\
\text { Singapore }\end{array}$ & CAS 9048-46-8, A8806-1G \\
\hline TRYPSIN-EDTA 10X & Biowest, USA & X0930-100 \\
\hline $\begin{array}{l}\text { Thermo Fisher } \\
\text { Subunit B, Alexa Fluor } \\
555 \text { Conjugate) }\end{array}$ & Cat: C34776 \\
\hline
\end{tabular}

\section{Method Details}

\section{Cell lines:}

Vero-81 (RRID:CVCL_0059), C6/36 mosquito cells and baby hamster kidney strain 21 (BHK21) fibroblast cells were from the American Type culture collection (ATCC). C6/36 were cells derived from larvae of female Aedes albopictus mosquito and were adapted to Eagle's minimum essential medium. Cells were cloned and re-cloned by seeding single cell suspensions into petri dishes. Further information about the cell lines can be obtained through Key Resources Table. 
375

376

377

378

379

380

381

382

383

384

\section{Cell culture:}

African green monkey kidney cells (Vero) and Baby hamster kidney cells (BHK21) were cultured in 10\% fetal bovine serum in Roswell Park Memorial Institute (RPMI) 1640 Medium with $25 \mathrm{mM}$ HEPES, and L-Glutamine, with $1 \%$ Penicillin-Streptomycin in $5 \% \mathrm{CO}_{2}$ at $37{ }^{\circ} \mathrm{C}$. Vero and BHK21 cells were a kind gift from Prof. Dr. Shee-Mei Lok, Duke-NUS Medical School, Singapore. Cells were passaged once they reached $90 \%$ confluence, by trypsinization ( $2 \mathrm{ml} 0.25 \%$ trypsin- $0.03 \%$ EDTA solution) for 2 minutes, and cells were re-seeded in new T75 flasks at a 1:5 or 1:10 split ratio with RPMI media (with 10\% FBS, 1\% PS, 25 mM HEPES and L-Glutamine).

\section{Virus preparation:}

DENV2 NGC and DENV1 PVP159 were produced and purified as previously described $(4,83)$. C6/36 mosquito cells were infected with DENV2 NGC and DENV1 PVP159 at an MOI of 0.1 and grown under $5 \% \mathrm{CO}_{2}$. The inoculant was replaced after 2 hours with RPMI medium supplemented with 2\% fetal bovine serum (FBS) and allowed to incubate for 4 days, after which the virus containing supernatant was clarified from cell debris by centrifugation. The virus particles were collected by precipitation with $8 \%$ polyethylene glycol 8000 (PEG 8000) in NTE buffer (10 mM Tris-HCl [pH 8.0], $120 \mathrm{mM} \mathrm{NaCl}, 1 \mathrm{mM}$ EDTA) and purified by centrifugation using a $30 \%$ sucrose cushion followed by a 10 to $30 \%$ potassium tartrate gradient. The virus band was collected and concentrated with a buffer exchange to NTE, using an Amicon Ultra-4 centrifugal concentrator (Millipore) with a $100-\mathrm{kDa}$ molecular-mass cutoff filter to obtain glycosylated native state virus particles. The virus preparation contained low levels of contamination by immature virus as determined by test for prM with a Coomassie blue-stained SDS-PAGE. The envelope protein concentration was estimated by comparing the 
corresponding band with that of bovine serum albumin (BSA) at different concentrations $[4,83,84]$.

\section{Viral labelling for fluorescence experiments:}

Purified DENV samples were labelled using either Alexa Fluor 555 NHS ester or Dil'(DiIC18(5)-DS) with $\sim 2.5 \times 10^{8} \mathrm{PFU}$ of the purified virus in $10 \mathrm{mM}$ HEPES, $150 \mathrm{mM}$ $\mathrm{NaCl}$ at $\mathrm{pH} 7.4$ (HN buffer) solution. The labelling was performed at a final concentration of $750 \mathrm{nM}$ and $100 \mathrm{nM}$ Alexa Fluor 555 NHS ester and DiI' (DiIC18(5)-DS) respectively (molar extinction coefficients of $71,000 \mathrm{M}^{-1} \mathrm{~cm}^{-1}$ and $144,000 \mathrm{M}^{-1} \mathrm{~cm}^{-1}$, respectively), and left at $4^{\circ} \mathrm{C}$ (to reduce loss of infectivity due to exposure to room temperature) for 2 hours. The Alexa Fluor 555 NHS ester labels the E protein on the virus, while the DiI' (DiIC18(5)-DS) labels the viral bilayer [84]. The free dye molecules were filtered out by size exclusion chromatography (MicroSpinTM S-200 HR columns).

\section{Preparation of GM1a for cell enrichment:}

The GM1a-Bodipy $25 \mu \mathrm{g}$ powder was first diluted in $50 \mu$ l chloroform: ethanol (19:1) solution, transferred to a clean $25 \mathrm{ml}$ round bottom flask, dried under nitrogen gas to evaporate the solvent and further dried under vacuum for 1 hour, after which it was dissolved using $200 \mu 1$ of absolute ethanol. This ethanol mixture of GM1a-Bodipy/GM1a was then mixed by vortexing into $0.34 \mathrm{mg} / \mathrm{mL}$ solution of defatted BSA in Hanks' buffered salt solution + $10 \mathrm{mM}$ HEPES, $\mathrm{pH} 7.4$ (HBSS/HEPES) to make a $3 \mu \mathrm{M}$ solution of GM1a in BSA which was aliquoted as 1 $\mathrm{mL}$ batches in Eppendorf tubes and stored at $-20{ }^{\circ} \mathrm{C}$, as recommended by the product information sheet. Similarly, Ganglioside GM1a solid was dissolved in a chloroform:ethanol (19:1) solution, to make a $10 \mathrm{mg} / \mathrm{ml}$ stock solution. From this a volume of $40 \mathrm{ml}$ was taken and 
423 imaging [85].

following the same protocol as above, a final stock of $5 \mu \mathrm{M}$ GM1 in BSA was prepared and stored at $-20{ }^{\circ} \mathrm{C}$ until experiment date.

\section{Treatment of cells with D-PDMP and enrichment of GM1a:}

The cells were trypsinized, and spun down in a $15 \mathrm{~mL}$ falcon tube at $1000 \mathrm{rpm}$ for 3 minutes to form a pellet. The cells were resuspended in $5 \mathrm{ml}$ RPMI (with 10\% FBS, 1\% PS, $25 \mathrm{mM}$ HEPES and L-Glutamine) and seeded at 2000 cells per well in an 8-well chambered coverglass (Thermo Scientific Nunc Lab-Tek Chambered coverglass). A solution of D-PDMP was diluted in $100 \%$ Ethanol to form a $10 \mathrm{mg} / \mathrm{mL}$ solution and diluted in $1 \times$ PBS to a final concentration of $0.5 \mathrm{mg} / \mathrm{ml}$ stock solution. This stock was diluted in cell culture media to prepare a solution of $10 \mu \mathrm{M}$. The cells were left to adhere to the coverglass, and after two hours, the media was replaced with media containing $10 \mu \mathrm{M}$ D-PDMP ((+)-D-threo-1-Phenyl-2decanoylamino-3-morpholino-1-propanol (hydrochloride)) and left for 2 days to inhibit endogenous GM1 synthesis in cells. The cells were rinsed three times with HBSS and were overlaid with $200 \mu \mathrm{l}$ volume at a concentration of $300 \mathrm{nM}$ or $100 \mathrm{nM}$ GM1a-Bodipy for imaging experiments and FCS/FCCS experiments respectively in Hanks' buffered salt solution + 10 mM HEPES, pH 7.4 (HBSS/HEPES). The GM1a-Bodipy was left on the cells for 30 minutes at $4{ }^{\circ} \mathrm{C}$, and washed three times with phenol red free RPMI (with $25 \mu \mathrm{M}$ HEPES). Labelled DENV was then overlaid at a multiplicity of infection (MOI) of 50 in phenol red free RPMI (with $25 \mu \mathrm{M}$ HEPES), at $4{ }^{\circ} \mathrm{C}$, then was washed and replaced with fresh media for 


\section{Transfection protocol:}

447 For transfection with GFP-GPI, cells were trypsinized, and the volume of 1 million cells (counted by Biorad tc10 automated cell counter, Bio-Rad Laboratories, Inc Singapore) was spun down in a $15 \mathrm{~mL}$ falcon tube at $1000 \mathrm{rpm}$ for 3 minutes to form a pellet. This pellet was resuspended in $9 \mu$ l electroporation buffer R (Neon transfection buffers), and gently mixed in with $500 \mathrm{ng}$ of GFP-GPI plasmid, and transfected using the Neon transfection System with a $10 \mu \mathrm{l}$ transfection tip using 1,200 pulse voltage (v), with 2 pulses. The cells were resuspended in $3 \mathrm{ml}$ RPMI (with 10\% FBS, $25 \mathrm{mM}$ HEPES and L-Glutamine), and were seeded $\sim 2000$ cells per well in 8-well chambered cover-glass (Thermo Scientific Nunc Lab-Tek Chambered Coverglass) and kept at $37^{\circ} \mathrm{C}$ in $5 \% \mathrm{CO}_{2}$.

\section{DiIC18(3) staining of live cell membrane:}

DiIC18(3) (1,1'-Dioctadecyl-3,3,3',3'-Tetramethylindocarbocyanine Perchlorate) was dissolved in DMSO and diluted to a final DiIC18(3) concentration of $100 \mathrm{nM}$ in $1 \times \mathrm{HBSS}$ with vortexing. Vero cells were rinsed three times with HBSS, and overlaid with $100 \mathrm{nM}$ solution and left at $37{ }^{\circ} \mathrm{C}$ in $5 \% \mathrm{CO}_{2}$ incubator for 15 minutes. The cells were then washed three times using phenol red free media and left in the same media for imaging and FCS/FCCS experiments.

\section{Plaque assay:}

BHK21 cells were grown till 90\% confluency in a T75 flask, and trypsinized. The trypsinyzed cell suspension in RPMI was centrifuged to remove debris and re-suspended in $50 \mathrm{~mL}$ of RPMI (with 10\% FBS, 1\% PS, $25 \mathrm{mM}$ HEPES and L-Glutamine). A volume of $1 \mathrm{ml}$ of this cell 
470

471

472

473

474

475

476

477

478

479

480

481

482

483

484

485

486

487

488

489

490

491

492

493

494

allow cells to form a continuous monolayer. The virus solution was serially diluted in ten-fold dilutions, using RPMI (with 4\% FBS, $25 \mathrm{mM}$ HEPES and L-Glutamine). The media was aspirated off of the cell monolayer, and a volume of $100 \mu \mathrm{l}$ of each dilution was added in triplicate to the wells. This was left to incubate at $37{ }^{\circ} \mathrm{C}$ with $5 \% \mathrm{CO}_{2}$, for 2 hours with plate tilting every 15 minutes to stop drying of cells. The virus overlay was then aspirated out, and a viscous overlay made up of RPMI with $1 \%$ Aquacide-II and 2\% FBS was placed over the cell monolayer, and left to incubate for 7 days. The plates were tipped to remove the viscous overlay, and stained using few drops of crystal violet $(0.5 \%$ (wt/vol) crystal violet $-25 \%$ formaldehyde), and was left for 1 hour, before washing under a running tap to remove unstained plaque areas. The plaques were counted by visual inspection and the PFU/ml was given by the (average number of plaques/ (Dilution factor $\times$ Volume of virus added $(\mathrm{mL}))$ ).

\section{Confocal microscope setup:}

An FV1200 confocal microscope (Olympus, Tokyo, Japan) equipped with a time-resolved FCS upgrade kit (PicoQuant, Berlin, Germany) was utilized in this work. The confocal was equipped with a pulsed $485 \mathrm{~nm}$ laser (LDH-D-C-488, PicoQuant, Germany) operated at 20 $\mathrm{MHz}$ repetition rate, a $543 \mathrm{~nm}$ continuous wave (cw) laser (GLG 7000, Showa Optronics, Japan), $488 \mathrm{~nm} \mathrm{cw}$ laser, and $635 \mathrm{~nm} \mathrm{cw}$ laser. All lasers were operated at $5 \mu \mathrm{W}$ power before the objective, on live cell membranes and passed through a $60 \mathrm{x}$, NA 1.2 water immersion objective (UplanSApo, Olympus, Japan), while the fluorescence emission is routed through a 405/488/543/635 dichroic mirror (Chroma Technology), confocal pinhole of one airy unit, and band-pass emission filters 513/17 (Brightline; Semrock, IDEX Health \& Science, LLC, New York) and a 615/45 (XF3025 32833, Omega Optical, USA) for green and red emissions in FCS 
and FCCS experiments. Band pass filter of BA505-525, and BA655-755, for green and red respectively was utilized for imaging and SPT experiments. The emission signal was detected by an avalanche photodiode (SPCM-AQR14; PerkinElmer). The photon counts from the detector were registered by a TimeHarp 260 time-correlated single photon counting board (PicoQuant) and processed by the SymPhoTime 64 software (PicoQuant) [86,87].

\section{FCS measurements on confocal microscope:}

FCS was performed on Vero cells at $37^{\circ} \mathrm{C}$, in phenol red free media with $25 \mu \mathrm{M}$ HEPES on a FV1200 confocal microscope (Olympus, Tokyo, Japan). FCS measurements in the green channel for GM1a-bodipy and GFP-GPI was performed by illuminating the sample with a pulsed $485 \mathrm{~nm}$ laser. FCS in the red channel for DiIC18(3) labelled cell membranes were performed by illumination with a $543 \mathrm{~nm}$ continuous wave (cw) laser. The signal was collected at detector without a beam splitter using a single detection channel and correlation functions were calculated using SymPhoTime 64 software (PicoQuant). Determination of dimensions of the effective detection volumes were performed by calibration of FCS measurements in solutions of reference dyes atto488 and atto565 (Atto-Tec, Siegen, Germany) of green and red channels respectively. The diffusion coefficient of Atto dyes was taken as $400 \mu \mathrm{m}^{2} / \mathrm{s}$ at room temperature, based on previously reported values [86-88].

\section{Fit models for confocal FCS measurements:}


519 For FCS in the confocal, in the simplest case, fluorescent molecules moving in 3D diffusion in

520 the confocal volume is fitted using a single particle (1p) 3D diffusion fit model.

$$
\begin{gathered}
G_{3 D, 1 p}(\tau)=\frac{1}{N}\left(1+\frac{\tau}{\tau_{D}}\right)^{-1}\left(1+\frac{\tau}{K^{2} \tau_{D}}\right)^{-\frac{1}{2}}+G_{\infty} \\
K=\frac{z_{0}}{\omega_{0}} \\
\tau_{D}=\frac{\omega_{0}^{2}}{4 D}
\end{gathered}
$$

522 where $K$ is the structure factor which defines the shape of the observation volume and $\tau_{D}$ is the 523 diffusion time.

524 In the case of 2D diffusion on cell membranes, the fitting model can be simplified as

$$
G_{2 D, 1 p}(\tau)=\frac{1}{N}\left(1+\frac{\tau}{\tau_{D}}\right)^{-1}+G_{\infty}
$$

527 If there are multiple diffusion components in the system, the linear sum of all these individual 528 components weighted with their respective mole fractions, gives the $G_{\tau}$, and can be expressed

$$
G_{2 D / 3 D, \text { multicomponant }}(\tau)=\frac{1}{N} \frac{\sum_{i=1}^{n} \alpha_{i}^{2} F_{i} g_{i}(\tau)}{\left(\sum_{i=1}^{n} \alpha_{i} F_{i}\right)^{2}}+G_{\infty}
$$




$$
\begin{gathered}
g_{i, 3 D}(\tau)=\left(1+\frac{\tau}{\tau_{D_{i}}}\right)^{-1}\left(1+\frac{\tau}{K^{2} \tau_{D_{i}}}\right)^{-\frac{1}{2}} \\
g_{i, 2 D}(\tau)=\left(1+\frac{\tau}{\tau_{D_{i}}}\right)^{-1}
\end{gathered}
$$

532 Where $\alpha_{i}$ is the ratio of the brightness of the $i^{\text {th }}$ species to that of species $1 . \tau_{D_{i}}$ is the diffusion

533 time and $F_{i}$ is the mole fraction of the $i^{t h}$ species.

534 The overall ACF is given as the product of all the individual dynamic processes that are present

535 in the system, including the triplet state relaxation of the fluorophore, and can be written as

536

$$
G_{t}(\tau)=1+\left(\frac{F_{\text {trip }}}{1-F_{\text {trip }}}\right) e^{\frac{\tau}{\tau_{\text {trip }}}}
$$

540 where $F_{\text {trip }}$ is the fraction of the triplet state and $\tau_{\text {trip }}$ is the relaxation time of the triplet state.

541 The fitting models for 2D and 3D diffusion with triplet contribution is as below

$$
G_{2 D, 1 p 1 t}(\tau)=\frac{1}{N}\left(1+\frac{\tau}{\tau_{D}}\right)^{-1}\left(1+\left(\frac{F_{\text {trip }}}{1-F_{\text {trip }}}\right) e^{-\frac{\tau}{\tau_{\text {trip }}}}\right)+G_{\infty}
$$




$$
G_{3 D, 2 p 1 t}(\tau)
$$

$$
\begin{aligned}
& =\frac{1}{N}\left[\left(1-F_{2}\right)\left(1+\frac{\tau}{\tau_{D 1}}\right)^{-1}\left(1+\frac{\tau}{K^{2} \tau_{D 1}}\right)^{-\frac{1}{2}}+F_{2}\left(1+\frac{\tau}{\tau_{D 2}}\right)^{-1}\left(1+\frac{\tau}{K^{2} \tau_{D 2}}\right)\right) \\
& \left(1+\frac{F_{\text {trip }}}{1-F_{\text {trip }}} e^{-\frac{\tau}{\tau_{\text {trip }}}}\right)+G_{\infty}
\end{aligned}
$$

$$
\begin{aligned}
G_{2 D, 2 p 1 t}(\tau)= & \frac{1}{N}\left(\left(1-F_{2}\right)\left(1+\frac{\tau}{\tau_{D 1}}\right)^{-1}+F_{2}\left(1+\frac{\tau}{\tau_{D 2}}\right)^{-1}\right) \\
& \left(1+\left(\frac{F_{\text {trip }}}{1-F_{\text {trip }}}\right) e^{-\frac{\tau}{\tau_{\text {trip }}}}\right)+G_{\infty}
\end{aligned}
$$

\section{FCCS on Confocal microscope:}

FCCS was performed on Vero cells at $37^{\circ} \mathrm{C}$, in phenol red free media with $25 \mu \mathrm{M}$ HEPES on a FV1200 confocal microscope (Olympus, Tokyo, Japan). Quasi-PIE FCCS was performed by using pulsed $485 \mathrm{~nm}$ and the $543 \mathrm{cw}$ laser to illuminate sample simultaneously. The emission was split by a 560DCXR (Chroma Technology, Bellows Falls, VT) emission dichroic filter cube to allow green and red emission to travel to the two separate detectors. The after pulsing and spectral cross talk was corrected by statistical filtering, using the FLCS script for spectral crosstalk removal via FLCCS on SymPhoTime 64 software (PicoQuant) [86,87]. 
558

559

560

$561 \quad[88]$.

$$
q=\frac{\max \left(N_{g} ; N_{r}\right)}{N_{x}}
$$

The derivation of $q$ factor is as below;

564

$$
\begin{gathered}
G_{G}(0)=\frac{1}{N_{G}}=\frac{N_{g}+N_{g r}}{\left(N_{g}+N_{g r}\right)^{2 \prime}} \\
G_{R}(0)=\frac{1}{N_{R}}=\frac{N_{r}+N_{g r}}{\left(N_{r}+N_{g r}\right)^{2}} \\
G_{G}(0)=\frac{1}{N_{x}}=\frac{N_{g r}}{\left(N_{g}+N_{g r}\right)\left(N_{r}+N_{g r}\right)}
\end{gathered}
$$

$$
\begin{gathered}
q=\frac{N_{g r}}{\min \left[\left(N_{g}+N_{g r}\right) ;\left(N_{r}+N_{g r}\right)\right]} \\
=\max \left[\frac{N_{g r}}{N_{g}+N_{g r}} ; \frac{N_{g r}}{N_{r}+N_{g r}}\right] \\
=\max \left[\frac{G_{X}(0)}{G_{R}(0)} ; \frac{G_{X}(0)}{G_{G}(0)}\right]=\frac{\max \left[N_{G} ; N_{R}\right]}{N_{X}}
\end{gathered}
$$


$N_{g}, N_{r}$ and $N_{x}$ are the background corrected particle numbers extracted from the ACFs in the green and red channel and from the CCF, respectively. Ten cell measurements with three 100 $\mathrm{s}$ acquisitions each where measured and the standard deviations of the $q$ mean was calculated for all measurements. The number of individual cells and measurement statistics are provided in the results section.

\section{D SPT of DENV on live cell membrane and imaging on Confocal:}

Vero cells were transfected with GFP-GPI and seeded in 8-well chambered cover-glasses. DENV labelled with DiI' (DiIC18(5)-DS) and overlaid on cells at $4{ }^{\circ} \mathrm{C}$ for 10 minutes. 2D SPT was performed by acquiring time lapse image series of labelled DENV on Vero cells at $37^{\circ} \mathrm{C}$, in phenol red free media with $25 \mu \mathrm{M}$ HEPES on a FV1200 confocal microscope (Olympus, Tokyo, Japan). Sample was illuminated with $488 \mathrm{~nm}$ laser for green probes, and excited with $635 \mathrm{~nm}$ laser in the red. The emission was passed through band pass filter of BA505-525, and BA655-755, for green and red respectively before being captured by the PMT. 512x512 pixel frame size at a sampling rate of $2.0 \mu \mathrm{s} /$ pixel (2.26 s/frame), and at a zoom level of x3, with $x y$ resolution of $0.137 \mu \mathrm{m} /$ pixel, and $z$ resolution of $1 \mu \mathrm{m}$, for 75 frames. The time-lapse image series was analysed using ImageJ plug-in mosaic [89] (MOSAIC Group, Centre for Systems Biology Dresden (CSBD), Dresden, Germany), to do particle localization and trajectory linking. The trajectories were extracted and analysed using the MATLAB class@msdanalyzer (built and maintained by Jean-Yves Tinevez, Institut Pasteur, France) [90] to generate MSD curves of trajectories, after correction for drift using velocity autocorrelation. These MSD curves were fitted using Igor Pro (WaveMetrics, Portland, OR) to obtain the diffusion coefficients of trajectories, in the case of Brownian motion, and velocities were obtained in the case of active transport. 
ImFCS (Imaging FCS) setup on TIRF microscope:

595

ImFCS was performed on an Olympus Inverted epi-fluorescence microscope 1X83 equipped

with a motorized TIRF illumination combiner (cel1^`TIRF/IX3-MITICO, Olympus) which

Olympus oil-immersion objective, the excitation laser was passed onto a ZT 405/488/561/640rpc (Chroma Technology, USA) dichroic mirror, to reflect the laser light on the back focal plane of the microscope objective. The laser light incident angle was adjusted to excited with the $488 \mathrm{~nm}$ excitation laser (Olympus Cell laser) at $100 \mu \mathrm{W}$ before the objective, and sample signal was acquired by collecting the fluorescence emission (after passing through the ZT 405/488/561/640rpc dichroic mirror), by filtering through a laser quad band

${ }^{\circ} \mathrm{C}$, with $5 \% \mathrm{CO}_{2}$ for all cell measurements.

\section{ImFCS on live cell membranes:}

614 Vero cells where transfected with GFP-GPI and treated with D-PDMP for two days to deplete 615 GM1. The cells were then enriched with GM1a. ImFCS measurements were carried out and 
DENV1, DENV2 and CTXB. DENV1, DENV2 and CTXB were labelled with Alexa fluor 555, and the cells measured after addition of DENV1, DENV2 or CTXB were first checked with $561 \mathrm{~nm}$ laser illumination (Olympus Cell laser), to confirm the presence of DENV1, DENV2 or CTXB on the cell of interest. A region of interest $(\mathrm{ROI})$ of $21 \times 21$ pixels $\left(5 \times 5 \mu \mathrm{m}^{2}\right)$ was selected from acquired image stacks away from cell edges for ImFCS and diffusion law analysis. The ACFs for all pixels in the image were calculated using a multi-tau correlation bleach correction [91]. The ACFs were fitted using the model in equation (19) on the home written ImFCS plugin which runs on ImageJ, to generate diffusion coefficient (D) maps and diffusion law plots.

\section{Imaging FCS diffusion law:}

FCS diffusion law $[92,93]$ exploits the space dependent property of membrane diffusion to explore and identify the mode of membrane organization in living cells. It is capable of differentiating between free diffusion, diffusion in domain partitioning and meshwork environments. Imaging FCS (ImFCS) $[80,94,95]$ is the adaptation of FCS diffusion law, where the dependence of diffusion time of the fluorophore $(\tau \mathrm{D})$ on observation area $\left(A_{e f f}\right)$ is described by $\tau_{D}\left(A_{e f f}\right)=\tau_{0}+A_{e f f} / D$. $A_{e f f}$ is given by the convolution of the detection area (or pixel area) with the point spread function and different $A_{\text {eff }}$ values were obtained by binning the pixels post-acquisition $(n \times n$ with $n=1-5)$. The magnitude and sign of intercept

$637 \tau_{0}$ indicates the mode of membrane diffusion and state of membrane packing. In a diffusion 638 law plot, free diffusion produces a straight line that passes through the origin with $\tau_{0}$ values of 639 $0.0 \pm 0.1 \mathrm{~s}$ [96]. Heterogeneous systems with domains or meshwork producing different 
640

641

642

643

644

645

646

$$
\begin{gathered}
\left.G(\tau)=\frac{1}{N}\left[\frac{\left.\operatorname{erf}(p(\tau))+\frac{\left(e^{-(p(\tau))^{2}}-1\right)}{\sqrt{\pi} p(\tau)}\right]^{2}+\left[1+\left(\frac{F_{t}}{1-F_{t}}\right) e^{\left(-\frac{\tau}{t_{f}}\right)}\right]+G_{\infty}}{\sqrt{\pi} p(0)}\right]^{-(p(0))^{2}}-1\right) \\
\sqrt{\pi}(p(0))+\frac{a}{\sqrt{4 D \tau+\omega_{0}^{2}}}
\end{gathered}
$$

Where $G(\tau)$ is the temporal autocorrelation function, $N$ is the number of particles, $a$ is the pixel size and $\omega_{0}$ is the $1 / e^{2}$ radius of Gaussian approximation of the microscope point spread 
657 Vero cells were seeded and treated with D-PDMP to deplete cells of endogenous unlabelled 658 GM1(99), and enriched with 50 nM GM1a-Bodipy, and overlaid with an MOI of 500 DENV1 or DENV2 for FCCS experiments. The DENV was labelled with Alexa fluor 555 NHS. FCCS was conducted at $37^{\circ} \mathrm{C}$ in phenol red free HEPES supplemented imaging media. The ACFs and the CCFs where calculated after FLCCS correction for detector cross-talk, and $q$ values were calculated.

DENV overlay on live Vero cells for imaging and 2D SPT:

Vero cells were plated on 8-well chambered cover-glass (Thermo Scientific Nunc Lab-Tek an MOI of 50, and overlaid on cells which were washed three times using phenol red free media. This was left at $4{ }^{\circ} \mathrm{C}$ for ten minutes to help virus reach the live cell membrane and to halt cellular endocytosis [99]. The 8-well chambered cover slides were then transferred to the microscope stage for imaging.

Deuterium labelling and quench conditions for Amide hydrogen deuterium exchange mass spectrometry:

Purified dengue virus solubilized in NTE buffer at $\mathrm{pH} 8.0$ was incubated at $37^{\circ} \mathrm{C}$ in PBS buffer reconstituted in $\mathrm{D}_{2} \mathrm{O}(99.90 \%)$ resulting in a final $\mathrm{D}_{2} \mathrm{O}$ concentration of $90 \%$. For generating DENV2: GM1a complex, viral particles were preincubated at a molar ratio of 1: 125 (E protein monomer: GM1a sugar) at $37^{\circ} \mathrm{C}$ for 30 min prior to each deuterium exchange reaction. 
Deuterium labelling was performed for 1 minute for both free and GM1a bound state followed by quenching the exchange reaction by adding prechilled quench buffer. Quench buffer contained 1.5 M GnHCl and 0.25 M Tris(2-carboxyethyl) phosphine-hydrochloride (TCEP$\mathrm{HCl}$ ) and after adding quench buffer the solution was incubated at $4{ }^{\circ} \mathrm{C}$ on ice for $30 \mathrm{sec}$ followed by addition of titanium dioxide to precipitate envelope lipids. Precipitated envelope lipids were removed before injecting the sample for pepsin digestion using $0.22 \mu \mathrm{m}$ centrifugal filters at $10000 \mathrm{rpm}$ for $1 \mathrm{~min}$. Deuterium exchange was also performed on free soluble E protein (1mg/ml, C-terminal (His) $)_{6}$ tag ) and sE protein: GM1a (1:50) for labelling times of 1, 10- and 100-min. sE protein was reported to exist dominantly in a monomeric and dimeric state at $37^{\circ} \mathrm{C}$ and $22^{\circ} \mathrm{C}$ respectively [101]. HDXMS was carried out at $22^{\circ} \mathrm{C}$ to map GM1a interactions to the dimeric state of E protein. Same quench conditions were used for both $\mathrm{sE}$ protein states with the exception that $\mathrm{E}$ protein from intact Dengue was treated with $\mathrm{TiO}_{2}$. This was not required for recombinant sE protein as it lacks stem helices and lipid membrane.

FCCS experiments have shown colocalization of GM1a glycosphingolipid with DENV2 and DENV1 showing the stable binding of GM1a to the viral surface. In the absence of equilibrium dissociation constant $\left(\mathrm{K}_{\mathrm{d}}\right)$, we used high molar ratio of GM1a sugar moiety to E protein (indicated above) in our deuterium exchange reactions. We observed no significant changes in sE protein (monomer) in the presence of GM1a at 1: 50 molar ratio either due to weak binding (high $\mathrm{K}_{\mathrm{d}}$ ) or lack of quaternary contacts akin to a virion. Also, no bimodal mass spectra was observed in sE protein: GM1a state to suggest partial or unsaturated binding of GM1a at virus E protein. Hence, in subsequent deuterium exchange reaction with DENV2 we used a higher concentration of DENV2 (E protein monomer) to GM1a molar ratio (1:125). Peptides showing protection in the presence of GM1a (DENV2: GM1a state) show unimodal distribution of mass spectra which suggests uniform binding across viral particle. 
706

707

708

709

710

711

712

713

714

715

716

717

718

719

720

721

722

723

724

725

726

727

728

729

730

\section{Mass Spectrometry and peptide identification:}

Quenched samples of $35 \mathrm{pmol}$ and 100 pmol from DENV2 and sE protein (free and GM1a complex states) were injected onto nanoUPLC HDX sample manager (Waters, Milford, MA) respectively. Injected samples were proteolyzed in online mode using pepsin immobilised Waters Enzymate column $(2.1 \times 30 \mathrm{~mm})$ in $0.1 \%$ formic acid in water at a flow rate of $100 \mu \mathrm{l} / \mathrm{min}$. The proteolyzed peptides were trapped in a $2.1 \times 5 \mathrm{~mm} \mathrm{C} 18$ trap (ACQUITY BEH C18 VanGuard Pre-column, $1.7 \mu \mathrm{m}$, Waters, Milford, MA). Elution of pepsin digested peptides was performed using acetonitrile (ACN) gradient of 8 to $40 \%$ in $0.1 \%$ formic acid at a flow rate of $40 \mu 1 \mathrm{~min}^{-1}$ into reverse phase column (ACQUITY UPLC BEH C18 Column, $1.0 \times$ $100 \mathrm{~mm}, 1.7 \mu \mathrm{m}$, Waters) pumped by nanoACQUITY Binary Solvent Manager (Waters, Milford, MA). Peptides were ionized using electrospray ionization mode and sprayed onto SYNAPT G2-Si mass spectrometer (Waters, Milford, MA). HDMSE mode acquisition and measurement was employed. $200 \mathrm{fmol}^{-1} \mathrm{l}^{-1}$ of $\left[\mathrm{Glu}^{1}\right]$-fibrinopeptide B ([Glu$\left.{ }^{1}\right]$-Fib) was injected at a flow rate of $5 \mu \mathrm{l} / \mathrm{min}$ into mass spectrometer for calibration and lockspray correction.

Protein Lynx Global Server v3.0 (PLGS v3.0) was used to identify the peptides from undeuterated mass spectra $\left(\mathrm{HDMS}^{\mathrm{E}}\right)$. Search for peptide identification was performed on sequence database of dengue 2 NGC strain with E, M and C protein. No specific protease and variable N-linked glycosylation modifications were chosen in search parameters to carry out the sequence identification. Peptide identification parameters intensity of 2500 for product and precursor ions, minimum products per amino acids of 0.2 and a precursor ion mass tolerance of $<10$ ppm using DynamX v.3.0 (Waters, Milford, MA). Peptides present in at least two out of three undeuterated samples were retained. Reported deuterium exchange values are uncorrected for back exchange and all the reactions are performed in triplicates. Three technical replicates were carried out for each deuterium exchange reaction for all 
bioRxiv preprint doi: https://doi.org/10.1101/2022.01.20.477180; this version posted January 21, 2022. The copyright holder for this preprint (which was not certified by peer review) is the author/funder, who has granted bioRxiv a license to display the preprint in perpetuity. It is made available under aCC-BY 4.0 International license.

states and their average values were used to generate the plots. Standard deviation within \pm 0.5

732 Da was observed for all the peptides. Therefore, a deuterium exchange difference of $\pm 0.5 \mathrm{Da}$

733 was chosen as significance threshold. List of peptides identified in the current HDXMS experiments is shown Supplementary file 1.

S.N.T. and T.W designed, analyzed, and interpreted the results. S.N.T performed and interpreted the FCCS, FCS, SPT, ImFCS, and biological assays. P.V.R. performed and interpreted the HDXMS experiments. J.C.W.B. produced and supplied virus samples. S.N.T., P.V.R., G.A. and T.W wrote the manuscript.

\section{DECLARATION OF INTERESTS}

744 The authors declare no competing interests. 
bioRxiv preprint doi: https://doi.org/10.1101/2022.01.20.477180; this version posted January 21, 2022. The copyright holder for this preprint (which was not certified by peer review) is the author/funder, who has granted bioRxiv a license to display the preprint in perpetuity. It is made available under aCC-BY 4.0 International license.

\section{References:}

1. Chen-Yu Hsu A, Jay Hirsch A, Laureti M, Narayanan D, Rodriguez-Andres J, Fazakerley JK, et al. Flavivirus Receptors: Diversity, Identity, and Cell Entry. Front Immunol | www.frontiersin.org [Internet]. 2018 [cited 2019 May 5];9:2180. Available from: www.frontiersin.org

2. Messina JP, Brady OJ, Golding N, Kraemer MUG, Wint GRW, Ray SE, et al. The current and future global distribution and population at risk of dengue. Nat Microbiol [Internet]. 2019 Jun 10 [cited 2019 Jun 29];1. Available from: http://www.nature.com/articles/s41564-019-0476-8

3. Kraemer MUG, Reiner RC, Brady OJ, Messina JP, Gilbert M, Pigott DM, et al. Past and future spread of the arbovirus vectors Aedes aegypti and Aedes albopictus. Nat Microbiol [Internet]. 2019 May 4 [cited 2019 Jun 29];4(5):854-63. Available from: http://www.nature.com/articles/s41564-019-0376-y

4. Fibriansah G, Ng T-S, Kostyuchenko VA, Lee J, Lee S, Wang J, et al. Structural changes in dengue virus when exposed to a temperature of $37^{\circ} \mathrm{C}$. J Virol [Internet]. 2013 Jul [cited 2017 Apr 23];87(13):7585-92. Available from: http://www.ncbi.nlm.nih.gov/pubmed/23637405

5. Brady OJ, Gething PW, Bhatt S, Messina JP, Brownstein JS, Hoen AG, et al. Refining the Global Spatial Limits of Dengue Virus Transmission by Evidence-Based Consensus. Reithinger R, editor. PLoS Negl Trop Dis [Internet]. 2012 Aug 7 [cited 2019 Jun 16];6(8):e1760. Available from: http://www.ncbi.nlm.nih.gov/pubmed/22880140

6. Bhatt S, Gething PW, Brady OJ, Messina JP, Farlow AW, Moyes CL, et al. The global distribution and burden of dengue. Nature [Internet]. 2013 Apr 7 [cited 2019 Jun 17];496(7446):504-7. Available from: http://www.nature.com/articles/nature12060

7. Vigerust DJ, Shepherd VL. Virus glycosylation: role in virulence and immune interactions. Trends Microbiol [Internet]. 2007 May 1 [cited 2019 May 12];15(5):2118. Available from: http://www.ncbi.nlm.nih.gov/pubmed/17398101

8. Kostyuchenko VA, Zhang Q, Tan JL, Ng T-S, Lok S-M. Immature and Mature Dengue Serotype 1 Virus Structures Provide Insight into the Maturation Process Downloaded from. J Virol [Internet]. 2013 [cited 2019 May 4];87:7700-7. Available from: http://jvi.asm.org/

9. Fibriansah G, Ibarra KD, Ng T-S, Smith SA, Tan JL, Lim X-N, et al. Cryo-EM structure of an antibody that neutralizes dengue virus type 2 by locking E protein dimers Downloaded from [Internet]. [cited 2019 May 1]. Available from: http://science.sciencemag.org/

10. Zhang Y, Zhang W, Ogata S, Clements D, Strauss JH, Baker TS, et al. Conformational Changes of the Flavivirus E Glycoprotein. [cited 2019 May 30]; Available from: https://www.ncbi.nlm.nih.gov/pmc/articles/PMC4152830/pdf/nihms618470.pdf

11. Zhang Y, Corver J, Chipman PR, Zhang W, Pletnev S V, Sedlak D, et al. Structures of immature flavivirus particles. EMBO J [Internet]. 2003 Jun 2 [cited 2019 May 30];22(11):2604-13. Available from: http://www.ncbi.nlm.nih.gov/pubmed/12773377

12. Pokidysheva E, Zhang Y, Battisti AJ, Bator-Kelly CM, Chipman PR, Xiao C, et al. 
bioRxiv preprint doi: https://doi.org/10.1101/2022.01.20.477180; this version posted January 21, 2022. The copyright holder for this preprint (which was not certified by peer review) is the author/funder, who has granted bioRxiv a license to display the preprint in perpetuity. It is made available under aCC-BY 4.0 International license.

Cryo-EM Reconstruction of Dengue Virus in Complex with the Carbohydrate Recognition Domain of DC-SIGN. Cell [Internet]. 2006 Feb 10 [cited 2019 May 1];124(3):485-93. Available from: https://www.sciencedirect.com/science/article/pii/S0092867406000079

13. Zhang X, Ge P, Yu X, Brannan JM, Bi G, Zhang Q, et al. Cryo-EM structure of the mature dengue virus at 3.5- $\AA$ resolution. Nat Struct Mol Biol [Internet]. 2013 Jan 16 [cited 2019 May 1];20(1):105-10. Available from: http://www.nature.com/articles/nsmb.2463

14. Cruz-Oliveira C, Freire JM, Conceição TM, Higa LM, Castanho MARB, Da Poian AT. Receptors and routes of dengue virus entry into the host cells. FEMS Microbiol Rev [Internet]. 2015 Mar 1 [cited 2019 May 5];39(2):155-70. Available from: http://academic.oup.com/femsre/article/39/2/155/635122/Receptors-and-routes-ofdengue-virus-entry-into

15. Mukhopadhyay S, Kuhn RJ, Rossmann MG. A structural perspective of the flavivirus life cycle. Nat Rev Microbiol [Internet]. 2005 Jan [cited 2016 Jan 25];3(1):13-22. Available from: http://www.ncbi.nlm.nih.gov/pubmed/15608696

16. Yap SSL, Nguyen-Khuong T, Rudd PM, Alonso S. Dengue Virus Glycosylation: What Do We Know? Front Microbiol [Internet]. 2017 [cited 2018 Dec 5];8:1415. Available from: http://www.ncbi.nlm.nih.gov/pubmed/28791003

17. Heinz FX, Stiasny K. Flaviviruses and their antigenic structure. J Clin Virol [Internet]. 2012 [cited 2019 May 4];55:289-95. Available from: http://dx.doi.org/10.1016/j.jcv.2012.08.024

18. Grove Joe, Marsh Mark. The cell biology of receptor-mediated virus entry. 2011 [cited 2018 Aug 30]; Available from: www.jcb.org/cgi/doi/10.1083/jcb.201108131JCB1071

19. Novel binding between pre-membrane protein and claudin-1 is required for efficient dengue virus entry. Biochem Biophys Res Commun [Internet]. 2010 Jan 1 [cited 2019 Jun 6];391(1):952-7. Available from: https://www-sciencedirectcom.libproxy1.nus.edu.sg/science/article/pii/S0006291X09023687?via\%3Dihub

20. Jindadamrongwech S, Thepparit C, Smith DR. Identification of GRP 78 (BiP) as a liver cell expressed receptor element for dengue virus serotype 2. Arch Virol [Internet]. 2004 May 1 [cited 2019 Jun 6];149(5):915-27. Available from: http://www.ncbi.nlm.nih.gov/pubmed/15098107

21. Chen YC, Wang SY, King CC. Bacterial lipopolysaccharide inhibits dengue virus infection of primary human monocytes/macrophages by blockade of virus entry via a CD14-dependent mechanism. J Virol [Internet]. 1999 Apr [cited 2019 Jun 6];73(4):2650-7. Available from: http://www.ncbi.nlm.nih.gov/pubmed/10074110

22. Cabrera-Hernandez A, Smith DR. Mammalian Dengue Virus Receptors. Dengue Bull $-.2005 ; 29$.

23. Meertens L, Carnec X, Lecoin MP, Ramdasi R, Guivel-Benhassine F, Lew E, et al. The TIM and TAM Families of Phosphatidylserine Receptors Mediate Dengue Virus Entry. Cell Host Microbe [Internet]. 2012 [cited 2019 Jun 6];12:544-57. Available from: http://dx.doi.org/10.1016/j.chom.2012.08.009

24. Reyes-del Valle J, Chavez-Salinas S, Medina F, del Angel RM. Heat Shock Protein 90 
bioRxiv preprint doi: https://doi.org/10.1101/2022.01.20.477180; this version posted January $21,2022$. The copyright holder for this preprint (which was not certified by peer review) is the author/funder, who has granted bioRxiv a license to display the preprint in perpetuity. It is made available under aCC-BY 4.0 International license.

and Heat Shock Protein 70 Are Components of Dengue Virus Receptor Complex in Human Cells. J Virol [Internet]. 2005 Apr 15 [cited 2016 Dec 28];79(8):4557-67. Available from: http://www.ncbi.nlm.nih.gov/pubmed/15795242

25. Hafirassou ML, Berlioz-Torrent C, Meertens L, Amara A. TIM-1 Ubiquitination Mediates Dengue Virus Entry. CellReports [Internet]. 2018 [cited 2019 Jun 6];23:1779-93. Available from: https://doi.org/10.1016/j.celrep.2018.04.013

26. Reyes-Del Valle J, Chávez-Salinas S, Medina F, Del Angel RM. Heat Shock Protein 90 and Heat Shock Protein 70 Are Components of Dengue Virus Receptor Complex in Human Cells Downloaded from. J Virol [Internet]. 2005 [cited 2019 Jun 6];79(8):4557-67. Available from: http://jvi.asm.org/

27. Hase T, Summers PL, Eckels KH. Flavivirus entry into cultured mosquito cells and human peripheral blood monocytes. Arch Virol [Internet]. 1989 [cited 2019 Jun 4];104(1-2):129-43. Available from: http://www.ncbi.nlm.nih.gov/pubmed/2564270

28. Acosta EG, Castilla V, Damonte EB. Alternative infectious entry pathways for dengue virus serotypes into mammalian cells. Cell Microbiol [Internet]. 2009 Oct [cited 2015 Sep 11];11(10):1533-49. Available from:

http://apps.webofknowledge.com.libproxy1.nus.edu.sg/full_record.do?product=WOS $\&$ search_mode $=$ GeneralSearch\&qid $=8 \& S I D=W 2$ t81R $1 \mathrm{kx} 34 \mathrm{BXSTxk} 7 \mathrm{a} \&$ page $=1 \& \mathrm{doc}$ $=1 \&$ cacheurlFromRightClick $=$ no

29. Merritt,' EA, Sarfaty,' Focco Van Den Akker,' Cecile L'hoir S, Martial,' And JA, Hol' WGJ. Crystal structure of cholera toxin B-pentamer bound to receptor GMl pentasaccharide [Internet]. Vol. 3, Protein Science. Cambridge University Press; 1994 [cited 2018 Nov 25]. Available from: https://www.ncbi.nlm.nih.gov/pmc/articles/PMC2142786/pdf/8003954.pdf

30. Merritt EA, Sarfaty S, Hol WGJ, Jobling MG, Holmes RK, Chang T, et al. Structural studies of receptor binding by cholera toxin mutants. Protein Sci [Internet]. 1997 Jul [cited 2019 Jun 8];6(7):1516-28. Available from:

http://www.ncbi.nlm.nih.gov/pubmed/9232653

31. Parton RG. Ultrastructural localization of gangliosides; GM1 is concentrated in caveolae. J Histochem Cytochem [Internet]. 1994 Feb 5 [cited 2019 Aug 10];42(2):155-66. Available from: http://www.ncbi.nlm.nih.gov/pubmed/8288861

32. Sandvig K, Sandvig K, van Deurs B. Ganglioside GM1 levels are a determinant of the extent of caveolae/raft-dependent endocytosis of cholera toxin to the Golgi apparatus. J Cell Sci [Internet]. 2003 Feb 1 [cited 2019 Aug 3];116(3):432-3. Available from: http://www.ncbi.nlm.nih.gov/pubmed/9472010

33. Rappaport J, Manthe RL, Solomon M, Garnacho C, Muro S, Author MP. A Comparative Study on the Alterations of Endocytic Pathways in Multiple Lysosomal Storage Disorders HHS Public Access Author manuscript. Mol Pharm [Internet]. 2016 [cited 2019 Aug 10];13(2):357-68. Available from: https://www.ncbi.nlm.nih.gov/pmc/articles/PMC4936955/pdf/nihms-794506.pdf

34. Challenges in design and characterization of ligand-targeted drug delivery systems. $\mathbf{J}$ Control Release [Internet]. 2012 Dec 10 [cited 2019 Aug 10];164(2):125-37. Available from: https://www-sciencedirectcom.libproxy1.nus.edu.sg/science/article/pii/S0168365912005111?via\%3Dihub 
bioRxiv preprint doi: https://doi.org/10.1101/2022.01.20.477180; this version posted January $21,2022$. The copyright holder for this preprint (which was not certified by peer review) is the author/funder, who has granted bioRxiv a license to display the preprint in perpetuity. It is made available under aCC-BY 4.0 International license.

35. Futerman AH, Hannun YA. The complex life of simple sphingolipids. EMBO Rep [Internet]. 2004 [cited 2019 Jun 8];5:777-82. Available from: http://embor.embopress.org/content/embor/5/8/777.full.pdf

36. Karlsson KA. Animal Glycosphingolipids as Membrane Attachment Sites for Bacteria. Annu Rev Biochem [Internet]. 1989 Jun 28 [cited 2019 Jun 8];58(1):309-50.

Available from: http://www.annualreviews.org/doi/10.1146/annurev.bi.58.070189.001521

37. Hakomori S. Traveling for the glycosphingolipid path. Glycoconj J [Internet]. [cited 2019 Jun 8];17(7-9):627-47. Available from: http://www.ncbi.nlm.nih.gov/pubmed/11421354

38. McFarland MA, Marshall AG, Hendrickson CL, Nilsson CL. Structural Characterization of the GM1 Ganglioside by Infrared Multiphoton Dissociation, Electron Capture Dissociation, and Electron Detachment Dissociation Electrospray Ionization FT-ICR MS/MS. Am Soc Mass Spectrom [Internet]. 2005 [cited 2018 Nov 23];(16):752-762. Available from: https://ac.els-cdn.com/S1044030505001133/1-s2.0S1044030505001133-main.pdf? tid=fa8077cb-ce91-43b3-bbfe7877d73c06b1\&acdnat=1542945934 789a660cf60ddaa9aca7b7976c24444a

39. Kolter T. Ganglioside Biochemistry. ISRN Biochem [Internet]. 2012 Dec 19 [cited 2019 Jun 8];2012:1-36. Available from: https://www.hindawi.com/archive/2012/506160/

40. Russo D, Parashuraman S, D'Angelo G. Glycosphingolipid-Protein Interaction in Signal Transduction. Int J Mol Sci [Internet]. 2016 Oct 15 [cited 2018 Apr 3];17(10):1732. Available from: http://www.ncbi.nlm.nih.gov/pubmed/27754465

41. Ledeen RW, Wu G. Special Issue: The Magic of the Sugar Code The multi-tasked life of GM1 ganglioside, a true factotum of nature. Trends Biochem Sci [Internet]. 2015 [cited 2018 Aug 14];40:407-18. Available from: http://dx.doi.org/10.1016/j.tibs.2015.04.005

42. Olofsson $\mathrm{S}$, Bergstro"m T, Bergstro"m B. Glycoconjugate glycans as viral receptors. [cited 2019 Jun 9]; Available from: https://www-tandfonlinecom.libproxy1.nus.edu.sg/doi/pdf/10.1080/07853890510007340?needAccess=true

43. Barton ES, Connolly JL, Forrest JC, Chappell JD, Dermody TS. Utilization of Sialic Acid as a Coreceptor Enhances Reovirus Attachment by Multistep Adhesion Strengthening*. 2000 [cited 2019 Jun 9]; Available from: http://www.jbc.org/

44. Stencel-Baerenwald JE, Reiss K, Reiter DM, Stehle T, Dermody TS. The sweet spot: defining virus-sialic acid interactions HHS Public Access. Nat Rev Microbiol [Internet]. 2014 [cited 2019 May 25];12(11):739-49. Available from: http://www.rcsb.org/pdb/home/home.do

45. Ravindran MS, Tanner LB, Wenk MR. Sialic acid linkage in glycosphingolipids is a molecular correlate for trafficking and delivery of extracellular cargo. Traffic [Internet]. 2013 Aug 1 [cited 2018 Nov 23];14(11):1182-91. Available from: http://doi.wiley.com/10.1111/tra.12100

46. Thompson AJ, de Vries RP, Paulson JC. Virus recognition of glycan receptors. Curr Opin Virol [Internet]. 2019 Feb [cited 2019 May 12];34:117-29. Available from: https://linkinghub.elsevier.com/retrieve/pii/S1879625718301494 
bioRxiv preprint doi: https://doi.org/10.1101/2022.01.20.477180; this version posted January $21,2022$. The copyright holder for this preprint (which was not certified by peer review) is the author/funder, who has granted bioRxiv a license to display the preprint in perpetuity. It is made available under aCC-BY 4.0 International license.

47. Ströh LJ, Ströh S, Stehle T. Glycan Engagement by Viruses: Receptor Switches and Specificity. 2014 [cited 2019 Jun 9]; Available from: www.annualreviews.org

48. De Graaf M, Fouchier RAM. Role of receptor binding specificity in influenza A virus transmission and pathogenesis. EMBO J [Internet]. 2014 [cited 2019 Jun 9];33:82341. Available from: www.who.int/influenza/human

49. Varki A, Cummings RD, Esko JD, Stanley P, Hart GW, Aebi M, et al. Essentials of Glycobiology [Internet]. Essentials of Glycobiology. Cold Spring Harbor Laboratory Press; 2015 [cited 2019 May 12]. Available from: http://www.ncbi.nlm.nih.gov/pubmed/27010055

50. Byrd-Leotis L, Cummings RD, Steinhauer DA, Byrd-Leotis L, Cummings RD, Steinhauer DA. The Interplay between the Host Receptor and Influenza Virus Hemagglutinin and Neuraminidase. Int J Mol Sci [Internet]. 2017 Jul 17 [cited 2019 Jun 9];18(7):1541. Available from: http://www.mdpi.com/1422-0067/18/7/1541

51. Maginnis MS. Virus-Receptor Interactions: The Key to Cellular Invasion. 2018 [cited 2019 May 12]; Available from: https://doi.org/10.1016/j.jmb.2018.06.024

52. Gillespie L, Roosendahl P, Ng WC, Brooks AG, Reading PC, Londrigan SL. Endocytic function is critical for influenza A virus infection via DC-SIGN and LSIGN. Nat Publ Gr [Internet]. 2015 [cited 2019 Jun 9]; Available from: www.nature.com/scientificreports/

53. Suzuki Y, Matsunaga M, Nagao Y, Taki T, Hirabayashi Y, Matsumoto M. Ganglioside GMlb as an influenza v rus receptor [Internet]. 1985 [cited 2018 Nov 23]. Available from: https://ac-els-cdn-com.libproxy1.nus.edu.sg/0264410X85901045/1-s2.00264410X85901045-main.pdf?_tid=79ed7db4-bc13-4be0-b8cb5a557123aea5\&acdnat $=1542946365 \_3 f f 207769$ c120548dedc063f01731c64

54. Nelson J, Couceiro SS, Paulson JC, Baum ' LG. Influenza virus strains selectively recognize sialyloligosaccharides on human respiratory epithelium; the role of the host cell in selection of hemagglutinin receptor specificity [Internet]. Vol. 29, IGus Research. 1993 [cited 2019 Jun 9]. Available from: https://pdf.sciencedirectassets.com/271060/1-s2.0-S0168170200X01025/1-s2.0016817029390056S/main.pdf?x-amz-securitytoken=AgoJb3JpZ2luX2VjEEgaCXVzLWVhc3QtMSJHMEUCIHcxmp83UGN2yAo KbOabsYTZYLVwwFZDvfXwJpDAW6bnAiEA0QPWfvN2Jh\%2FtgqBOfQwb01OZ wHxae95Uibda1lueN\%2Fsq2gMIcBACGgwwNTkwMDM1NDY4NjUiDKEexHJP8 RqJT25qriq3A\%2BogRf8TpNRn1SzLqz29F8SBzbsFcRB4kIxHIlA0yZQ25bzSvs3wI 4vwthujtf\%2FoKnUOsdW\%2FcvVE3Br1r0yoId6nK4CBzQ8PobCyIj71XsxIckrgsR2a m4QgBGA6rMFGzTpY\%2BgWw7Sj2mgirwFXhAm\%2FD\%2Fq3yInEg0abcm16Kb y3itT543gP6YyCzf66arqtMrsdJ9WHhDfMsOyU7c1g3rYdhYOKXdWgJ\%2FXvFNd cfPk0jXbKNoDxwALN5\%2Be9vrWKcKhUFpJssMqaTy5Ec9iNJAu3z4kp2qnfFvdV 6ISoRkJ5cmPtHidYGvlDWcqXw\%2BaqA33QYt7Ow70ToH1DV\%2FNtdN89qHIPB txjv177WF5\%2FMM56297rB\%2F8oWQB0\%2BSMSBYNKcnt9qL\%2FiN1ZM3Jnpg Ai5TnBbNIk6N2XX9qYL1gV5Wf5ILBE1VbXU5Gv\%2BzoEhy\%2F65blYCdLK\%2 BqVMwgJVLWouMvtiwZ1iEWm5Bme8itrPFDjdKFS97EfR97ToPCyP4AnjI1PITtJF rQhV6F1O\%2BdXpIwZ8cjMZmmedWvho\%2FWtoZDruTGBVx55Zqs3N0F9rsSJ1rA iU657yBhrTAw1ePy5wU6tAFLseM3AEcWCNanboWLHSwPNuZqb5xuxud9bX2km XMJh4UScejx1gVMsMblVODMrTN14GieTZXh9iewAyqqcmBNA0CZZ0BmsdQC LkQVf1WWdc4HYcUJMJ3htg0LlvRjjs9UfqNTf\%2BLj6gOHWbCXygjNnvTLFOsR 
bioRxiv preprint doi: https://doi.org/10.1101/2022.01.20.477180; this version posted January $21,2022$. The copyright holder for this preprint (which was not certified by peer review) is the author/funder, who has granted bioRxiv a license to display the preprint in perpetuity. It is made available under aCC-BY 4.0 International license.

cQnqXbqOqkPhd\%2BqSs9SQIPcdjfqWesbKMD6MJ2rHu51Qb4AzGsIMEIXwW8Hj s\%2FXpox8\%2FTTQYK62CtoJrIwE\%3D\&AWSAccessKeyId=ASIAQ3PHCVTYW FNGWWQK\&Expires $=1560067827 \&$ Signature $=u 3 i B f i c s H z T 4 j h m q O u X G D M o T Z z I$ \%3D\&hash=0589d196363c13644b4a9ff93449c3ec3bddf6100b65762569817be4aebdc $\mathrm{d} 8 \mathrm{c} \&$ host $=68042 \mathrm{c} 943591013 \mathrm{ac} 2 \mathrm{~b} 2430 \mathrm{a} 89 \mathrm{~b} 270 \mathrm{fbaf2c76d} 8 \mathrm{dfd} 086 \mathrm{a} 07176 \mathrm{afe} 7 \mathrm{c} 76 \mathrm{c} 2 \mathrm{c} 6$ 1\&pii=016817029390056S\&tid=spdf-93af0744-36af-4fcf-a8d8cc204c705209\&sid=8a685de748e7b14cec489ec99be58efd12dagxrqb\&type=client

55. Watowich SJ, Skehel JJ, Wiley DC. Crystal structures of influenza virus hemagglutinin in complex with high-affinity receptor analogs [Internet]. [cited 2019 May 25]. Available from: https://www.cell.com/action/showPdf?pii=S0969$2126 \% 2800 \% 2900073-3$

56. Bowden TA, Crispin M, Jones EY, Stuart DI. Shared paramyxoviral glycoprotein architecture is adapted for diverse attachment strategies. Biochem Soc Trans [Internet]. 2010 Oct 1 [cited 2019 Jun 9];38(5):1349-55. Available from: http://www.ncbi.nlm.nih.gov/pubmed/20863312

57. Ann Markwell MK, SVENNERHOLMt L, PAULSONt JC, Boyer PD. Specific gangliosides function as host cell receptors for Sendai virus. (paramyxovirus/Nacetylneuraminic acid/sialoglycoconjugate/celi membrane glycolipids/Madin-Darby bovine kidney epithelial cells) Communicated by [Internet]. Vol. 78. 1981 [cited 2019 May 12]. Available from: https://www.pnas.org/content/pnas/78/9/5406.full.pdf

58. Campanero-Rhodes MA, Smith A, Chai W, Sonnino S, Mauri L, Childs RA, et al. NGlycolyl GM1 Ganglioside as a Receptor for Simian Virus $40 \dagger$. J Virol [Internet]. 2007 [cited 2019 May 12];81(23):12846-58. Available from: http://jvi.asm.org/

59. Neu U, Woellner K, Gauglitz G, Stehle T. Structural basis of GM1 ganglioside recognition by simian virus 40. Proc Natl Acad Sci [Internet]. 2008 Apr 1 [cited 2018 Nov 25];105(13):5219-24. Available from: http://www.ncbi.nlm.nih.gov/pubmed/18353982

60. Tsai B, Gilbert JM, Stehle T, Lencer W, Benjamin L, Rapoport TA. Gangliosides are receptors for murine polyoma virus and SV40. EMBO J. 2003;22 (17):4346-55.

61. Liu C, Tang J, Ma Y, Liang X, Yang Y, Peng G, et al. Receptor usage and cell entry of porcine epidemic diarrhea coronavirus. J Virol [Internet]. 2015 Jun 1 [cited 2019 Jun 9];89(11):6121-5. Available from: http://www.ncbi.nlm.nih.gov/pubmed/25787280

62. Memish ZA, Cotten M, Meyer B, Watson SJ, Alsahafi AJ, Al Rabeeah AA, et al. Human Infection with MERS Coronavirus after Exposure to Infected Camels, Saudi Arabia, 2013. Emerg Infect Dis [Internet]. 2014 Jun [cited 2019 Jun 9];20(6):1012-5. Available from: http://www.ncbi.nlm.nih.gov/pubmed/24857749

63. Schwegmann-Weßels C, Herrler G. Sialic acids as receptor determinants for coronaviruses. Glycoconj J [Internet]. 2006 [cited 2019 Jun 9];23:51-8. Available from: https://link-springer-com.libproxy1.nus.edu.sg/content/pdf/10.1007\%2Fs10719006-5437-9.pdf

64. Hulswit RJG, De Haan CAM, Bosch B-J. Coronavirus Spike Protein and Tropism Changes. 2016 [cited 2019 Jun 9]; Available from: http://dx.doi.org/10.1016/bs.aivir.2016.08.004

65. Kim D-S, Son K-Y, Koo K-M, Kim J-Y, Alfajaro MM, Park J-G, et al. Porcine 
bioRxiv preprint doi: https://doi.org/10.1101/2022.01.20.477180; this version posted January $21,2022$. The copyright holder for this preprint (which was not certified by peer review) is the author/funder, who has granted bioRxiv a license to display the preprint in perpetuity. It is made available under aCC-BY 4.0 International license.

Sapelovirus Uses $\alpha 2,3$-Linked Sialic Acid on GD1a Ganglioside as a Receptor. J Virol [Internet]. 2016 Apr 15 [cited 2019 Jun 9];90(8):4067-77. Available from: http://www.ncbi.nlm.nih.gov/pubmed/26865725

66. Zocher G, Mistry N, Frank M, Hähnlein-Schick I, Ekström J-O, Arnberg N, et al. A Sialic Acid Binding Site in a Human Picornavirus. Rey FA, editor. PLoS Pathog [Internet]. 2014 Oct 16 [cited 2019 Jun 9];10(10):e1004401. Available from: http://dx.plos.org/10.1371/journal.ppat.1004401

67. Imamura T, Okamoto M, Nakakita S, Suzuki A, Saito M, Tamaki R, et al. Antigenic and receptor binding properties of enterovirus 68. J Virol [Internet]. 2014 Mar 1 [cited 2019 Jun 9];88(5):2374-84. Available from:

http://www.ncbi.nlm.nih.gov/pubmed/24371050

68. Nguyen L, McCord KA, Bui DT, Bouwman KM, Kitova EN, Elaish M, et al. Sialic acid-containing glycolipids mediate binding and viral entry of SARS-CoV-2. Nat Chem Biol 2021 [Internet]. 2021 Nov 9 [cited 2021 Nov 22];1-10. Available from: https://www.nature.com/articles/s41589-021-00924-1

69. Löfling J, Lyi SM, Parrish CR, Varki A. Canine and feline parvoviruses preferentially recognize the non-human cell surface sialic acid N-glycolylneuraminic acid. Virology [Internet]. 2013 May 25 [cited 2019 Jun 9];440(1):89-96. Available from: http://www.ncbi.nlm.nih.gov/pubmed/23497940

70. Stuart AD, Brown TDK. 2,6-Linked sialic acid acts as a receptor for Feline calicivirus. J Gen Virol [Internet]. 2007 Jan 1 [cited 2019 Jun 9];88(1):177-86. Available from: http://jgv.microbiologyresearch.org/content/journal/jgv/10.1099/vir.0.82158-0

71. Burmeister WP, Guilligay D, Cusack S, Wadell G, Arnberg N. Crystal Structure of Species D Adenovirus Fiber Knobs and Their Sialic Acid Binding Sites. J Virol [Internet]. 2004 Jul 15 [cited 2019 Jun 9];78(14):7727-36. Available from: http://www.ncbi.nlm.nih.gov/pubmed/15220447

72. Nilsson EC, Storm RJ, Bauer J, Johansson SMC, Lookene A, Ångström J, et al. The GD1a glycan is a cellular receptor for adenoviruses causing epidemic keratoconjunctivitis. Nat Med [Internet]. 2011 Jan 12 [cited 2019 Jun 9];17(1):105-9. Available from: http://www.ncbi.nlm.nih.gov/pubmed/21151139

73. Spiropoulou CF, Kunz S, Rollin PE, Campbell KP, Oldstone MBA. New World arenavirus clade $\mathrm{C}$, but not clade $\mathrm{A}$ and $\mathrm{B}$ viruses, utilizes alpha-dystroglycan as its major receptor. J Virol [Internet]. 2002 May [cited 2019 Jun 9];76(10):5140-6. Available from: http://www.ncbi.nlm.nih.gov/pubmed/11967329

74. Cao W, Henry MD, Borrow P, Yamada H, Elder JH, Ravkov E V, et al. Identification of alpha-dystroglycan as a receptor for lymphocytic choriomeningitis virus and Lassa fever virus. Science [Internet]. 1998 Dec 11 [cited 2019 Jun 9];282(5396):2079-81. Available from: http://www.ncbi.nlm.nih.gov/pubmed/9851928

75. Padilla-Parra S, Audugé N, Coppey-Moisan M, Tramier M. Dual-color fluorescence lifetime correlation spectroscopy to quantify protein-protein interactions in live cell. Microsc Res Tech [Internet]. 2011 Aug 1 [cited 2021 Oct 5];74(8):788-93. Available from: https://onlinelibrary.wiley.com/doi/full/10.1002/jemt.21015

76. Foo YH, Naredi-Rainer N, Lamb DC, Ahmed S, Wohland T. Factors Affecting the Quantification of Biomolecular Interactions by\&nbsp;Fluorescence Cross-Correlation 
bioRxiv preprint doi: https://doi.org/10.1101/2022.01.20.477180; this version posted January $21,2022$. The copyright holder for this preprint (which was not certified by peer review) is the author/funder, who has granted bioRxiv a license to display the preprint in perpetuity. It is made available under aCC-BY 4.0 International license.

Spectroscopy. 2012;

77. Modis Y, Ogata S, Clements D, Harrison SC. A ligand-binding pocket in the dengue virus envelope glycoprotein [Internet]. [cited 2018 Aug 30]. Available from: www.pnas.orgcgidoi10.1073pnas.0832193100

78. Fujinaga Y, Wolf AA, Rodighiero C, Wheeler H, Tsai B, Allen L, et al. Gangliosides that associate with lipid rafts mediate transport of cholera and related toxins from the plasma membrane to endoplasmic reticulm. Mol Biol Cell [Internet]. 2003 Dec [cited 2019 Oct 9];14(12):4783-93. Available from: http://www.ncbi.nlm.nih.gov/pubmed/13679513

79. Simons K, Sampaio JL. Membrane organization and lipid rafts. Cold Spring Harb Perspect Biol [Internet]. 2011 Oct 1 [cited 2019 Oct 9];3(10):a004697. Available from: http://www.ncbi.nlm.nih.gov/pubmed/21628426

80. Sankaran J, Shi X, Ho LY, Stelzer EHK, Wohland T. ImFCS: A software for Imaging FCS data analysis and visualization. Opt Express [Internet]. 2010 Dec 6 [cited 2019 Aug 6];18(25):25468. Available from: https://www.osapublishing.org/oe/abstract.cfm?uri=oe-18-25-25468

81. Raghunathan K, Wong TH, Chinnapen DJ, Lencer WI, Jobling MG, Kenworthy AK. Glycolipid Crosslinking Is Required for Cholera Toxin to Partition Into and Stabilize Ordered Domains. Biophys J [Internet]. 2016 Dec [cited 2019 Aug 3];111(12):254750. Available from: https://linkinghub.elsevier.com/retrieve/pii/S0006349516310359

82. S Štefl M, Šachl R, Humpolíčková J, Cebecauer M, Macháň R, Kolářová M, et al. Dynamics and Size of Cross-Linking-Induced Lipid Nanodomains in Model Membranes. Biophys J [Internet]. 2012 May [cited 2019 Aug 3];102(9):2104-13. Available from: https://linkinghub.elsevier.com/retrieve/pii/S0006349512003955

83. Lim X-X, Chandramohan A, Lim XYE, Bag N, Sharma KK, Wirawan M, et al. Conformational changes in intact dengue virus reveal serotype-specific expansion. Nat Commun [Internet]. 2017 Feb 10 [cited 2017 Apr 23];8:14339. Available from: http://www.nature.com/doifinder/10.1038/ncomms14339

84. Sharma KK, Lim X-X, Tantirimudalige SN, Gupta A, Marzinek JK, Holdbrook D, et al. Infectivity of Dengue Virus Serotypes 1 and 2 Is Correlated with E-Protein Intrinsic Dynamics but Not to Envelope Conformations. Structure [Internet]. 2019 Jan 24 [cited 2019 Mar 17]; Available from: https://www-sciencedirectcom.libproxy1.nus.edu.sg/science/article/pii/S0969212618304623

85. Nagafuku M, Kabayama K, Oka D, Kato A, Tani-Ichi $\ddagger$ S, Shimada Y, et al. Reduction of Glycosphingolipid Levels in Lipid Rafts Affects the Expression State and Function of Glycosylphosphatidylinositol-anchored Proteins but Does Not Impair Signal Transduction via the T Cell Receptor*. 2003 [cited 2018 Aug 28]; Available from: http://www.jbc.org/

86. Kapusta P, Macháň R, Benda A, Hof M. Fluorescence Lifetime Correlation Spectroscopy (FLCS): Concepts, Applications and Outlook. Int J Mol Sci [Internet]. 2012 [cited 2017 Jan 6];13:12890-910. Available from: www.mdpi.com/journal/ijms

87. Padilla-Parra S, Audugé N, Coppey-Moisan M, Tramier M. Dual-color fluorescence lifetime correlation spectroscopy to quantify protein-protein interactions in live cell. Microsc Res Tech [Internet]. 2011 Aug [cited 2019 Jun 16];74(8):788-93. Available 
bioRxiv preprint doi: https://doi.org/10.1101/2022.01.20.477180; this version posted January $21,2022$. The copyright holder for this preprint (which was not certified by peer review) is the author/funder, who has granted bioRxiv a license to display the preprint in perpetuity. It is made available under aCC-BY 4.0 International license.

from: http://www.ncbi.nlm.nih.gov/pubmed/21618649

88. Kapusta P. Absolute Diffusion Coefficients: Compilation of Reference Data for FCS Calibration. 2010 [cited 2021 Dec 23]; Available from: http://dx.doi.org/10.1002/cphc.200600638

89. Kohl T, Haustein E, Schwille P. Determining Protease Activity In Vivo by Fluorescence Cross-Correlation Analysis. [cited 2019 Jun 15]; Available from: https://www.ncbi.nlm.nih.gov/pmc/articles/PMC1366777/pdf/2770.pdf

90. Sbalzarini IF, Koumoutsakos P. Feature point tracking and trajectory analysis for video imaging in cell biology. J Struct Biol [Internet]. 2005 Aug [cited 2016 Feb 23];151(2):182-95. Available from: http://www.ncbi.nlm.nih.gov/pubmed/16043363

91. Tarantino N, Tinevez J-Y, Crowell EF, Boisson B, Henriques R, Mhlanga M, et al. TNF and IL-1 exhibit distinct ubiquitin requirements for inducing NEMO-IKK supramolecular structures. J Cell Biol [Internet]. 2014 Jan 20 [cited 2019 Jun 30];204(2):231-45. Available from: http://www.ncbi.nlm.nih.gov/pubmed/24446482

92. Macháň R, Foo YH, Wohland T. On the Equivalence of FCS and FRAP: Simultaneous Lipid Membrane Measurements. Biophys J [Internet]. 2016 Jul 12 [cited 2019 Aug 6];111(1):152-61. Available from: https://www.sciencedirect.com/science/article/pii/S0006349516303988

93. Wawrezinieck L, Rigneault H, Marguet D, Lenne P-FX. Fluorescence Correlation Spectroscopy Diffusion Laws to Probe the Submicron Cell Membrane Organization. [cited 2019 Jul 28]; Available from: https://www-cellcom.libproxy1.nus.edu.sg/action/showPdf?pii=S0006-3495\%2805\%2973044-7

94. Ruprecht V, Wieser S, Marguet D, Schütz GJ. Spot variation fluorescence correlation spectroscopy allows for superresolution chronoscopy of confinement times in membranes. Biophys J. 2011 Jun 8;100(11):2839-45.

95. Ng XW, Bag N, Wohland T. Characterization of Lipid and Cell Membrane Organization by the Fluorescence Correlation Spectroscopy Diffusion Law. Chim Int J Chem [Internet]. 2015;69(3):112-9. Available from: http://openurl.ingenta.com/content/xref?genre=article\&issn=0009$4293 \&$ volume $=69 \&$ issue $=3 \&$ spage $=112$

96. Sankaran J, Bag N, Kraut RS, Wohland T. 3948-3954 Downloaded via NATL UNIV OF SINGAPORE on March 30. Anal Chem [Internet]. 2013 [cited 2021 Mar 30];85. Available from: https://pubs.acs.org/sharingguidelines

97. Sankaran J, Bag N, Kraut RS, Wohland T. Accuracy and precision in camera-based fluorescence correlation spectroscopy measurements. Anal Chem [Internet]. $2013 \mathrm{Apr}$ 16 [cited 2021 Apr 6];85(8):3948-54. Available from: https://pubs.acs.org/sharingguidelines

98. Huang S, Lim SY, Gupta A, Bag N, Wohland T. Plasma membrane organization and dynamics is probe and cell line dependent. 2016;

99. Nagafuku M, Kabayama K, Oka D, Kato A, Tani-Ichi $\$$ S, Shimada Y, et al. Reduction of Glycosphingolipid Levels in Lipid Rafts Affects the Expression State and Function of Glycosylphosphatidylinositol-anchored Proteins but Does Not Impair Signal Transduction via the T Cell Receptor*. 2003 [cited 2018 Aug 30]; Available from: 
bioRxiv preprint doi: https://doi.org/10.1101/2022.01.20.477180; this version posted January 21, 2022. The copyright holder for this preprint (which was not certified by peer review) is the author/funder, who has granted bioRxiv a license to display the preprint in perpetuity. It is made available under aCC-BY 4.0 International license.

http://www.jbc.org/

100. Mosso C, Galván-Mendoza IJ, Ludert JE, del Angel RM. Endocytic pathway followed by dengue virus to infect the mosquito cell line C6/36 HT. Virology [Internet]. 2008 Aug 15 [cited 2019 Jun 1];378(1):193-9. Available from: https://www.sciencedirect.com/science/article/pii/S0042682208003140?via\%3Dihub

101. Kudlacek ST, Premkumar L, Metz SW, Tripathy A, Bobkov AA, Matthew Payne A, et al. Physiological temperatures reduce dimerization of dengue and Zika virus recombinant envelope proteins and the Downloaded from. J Biol Chem [Internet]. 2018 [cited 2020 Mar 20];(23):8922-33. Available from: http://www.jbc.org/ 
Figure legends:

Fig 1. Representative FCCS curves obtained by quasi-PIE FCCS.

(A) FCCS positive control of PMT-mEGFP-mApple with a q value of 0.54. (B) FCCS negative

control of non-interacting partners GM1a-Bodipy and DiI-C18 with a q value of 0. (C) GM1a interaction with DENV1 with a q value of 0.15 (D) GM1a interaction with DENV2 with a q distribution of DENV1 and DENV2 interaction with GM1a compared with the negative and positive controls. Overall q values of $0.15 \pm 0.02($ cells $=19), 0.21 \pm 0.02($ cells $=58), 0.45 \pm 0.01$ $($ cells $=10), 0.03 \pm 0.01($ cells $=6)$ for DENV1, DENV2, positive control of PMT-mEGFPmApple and negative control with DiIC18 (Avg \pm SEM). Error bars represent the standard deviation. All cells were pre-treated with DPDMP to inhibit endogenous GM1a production.

Fig 2. HDX-MS reveal GM1a sugar moiety binding hotspot on Denv2 NGC surface on $E$

protein

(A) Differences in average number of deuterons exchanged (Y-axis) in DENV2:GM1a state and free Denv2 state are plotted in a deuterium uptake difference plot for $\mathrm{t}=1 \mathrm{~min}$ labelling time. Pepsin digested peptides are listed from $\mathrm{N}$ to $\mathrm{C}$ terminus (X-axis). Peptide regions showing high protection in the presence of GM1a are highlighted. Standard deviations are shaded gray and plots were generated using DynamX 3.0 software. The data is uncorrected for maximum deuterium content of $90 \%$ under experimental conditions, and unadjusted to accommodate loss in deuterons exchanged due to back-exchange (average back-exchange $\sim 15 \%$ under our HDXMS conditions). (B) Representative mass spectra of peptides protected in the presence of 
mass spectra (C) Differences in deuterium exchange between DENV2-GM1a bound and free DENV2 are mapped onto a E protein dimer (PDB: 3J27) with differences highlighted as per key (D) Peptides protected in the presence of GM1a sugar are mapped in blue onto the full virus (PDB:3J27). Red spheres represent glycans on viral surface.

\section{Fig 3. Infectivity changes of DENV1 and DENV2 by plaque assay in presence and absence} of GM1a.

(A) DENV1 with GM1a shows an increase in infectivity, while the GM1a depleted condition shows a reduction in infectivity as compared to the untreated cells. (B) DENV2 with GM1a shows a substantial increase in infectivity, while the GM1a depleted condition shows a reduction in infectivity as compared to the untreated cells. Error bars represent the SEM.

\section{Fig 4. Distribution of diffusion coefficients from MSD curves for DENV on live Vero cell} membrane surface.

(A) The normalized distributions of DENV1 compared with DENV1-GM1a, and DENV2 with DENV2-GM1a. The virus once colocalized with GM1a shows a population shift toward increased diffusion coefficients (B) Average \pm SEM shown, with diffusion coefficient distribution of 2D SPT tracks of DENV1, and DENV2 labelled with DiI', in presence and absence of GM1a-Bodipy. The distribution of diffusion coefficient of DENV1 increase from $0.005 \pm 0.001 \mu \mathrm{m}^{2} / \mathrm{s}(\operatorname{Avg} \pm \mathrm{SEM} ;$ tracks $=258)$ to $0.01 \pm 0.002 \mu \mathrm{m}^{2} / \mathrm{s}(\operatorname{Avg} \pm \mathrm{SEM} ;$ tracks $=86)$ for with and without colocalization with GM1a respectively (not statistically significant at $\alpha=$ 0.05), while DENV2 diffusion coefficient distribution shows a shift to from $0.005 \pm 0.001$ $\mu \mathrm{m}^{2} / \mathrm{s}(\operatorname{Avg} \pm \mathrm{SEM}$; tracks $=483)$ to a higher $\mathrm{D}$ of $0.015 \pm 0.002 \mu \mathrm{m}^{2} / \mathrm{s}(\mathrm{Avg} \pm \mathrm{SEM}$; tracks $=$ 
415) when colocalized with GM1a. Cells were pre-treated with D-PDMP to deplete GM1a for trajectories of DENV with no GM1a. Cells pre-treated with D-PDMP were enriched with GM1a-Bodipy and colocalized trajectories are presented as DENV-GM1a.

Fig 5. Diffusion coefficients and Diffusion law intercepts of GFP-GPI raft probe on live Vero cell membrane measured by ImFCS.

(A) Comparison of diffusion coefficient of the raft-marker GFP-GPI, on cells treated with DPDMP+GM1a, to observe the effect of DENV1, DENV2, and CTXB interaction with GM1a. (B) ImFCS Diffusion law intercept $\tau_{0}$ changes of the raft-marker GFP-GPI, on cells treated with D-PDMP+GM1a, to observe the effect of DENV1, DENV2, and CTXB interaction with GM1a. Error bars in both graphs represent the SD.

(1)


Supplementary Figure legends:

S1 Fig. Controls for FCCS experiments.

FCCS control experiment to confirm no unfiltered dye interferes with the FCCS results. FCCS curves for Spin filtered solution resulting from starting solution of $500 \mathrm{nM}$ concentration Alexa flour 555 on cells incorporated with GM1a-Bodipy gives no signal in the red channel and no cross correlation, indicating no excess dye is present under the conditions used for labelling DENV. Cells were pre-treated with DPDMP before enriching with GM1a

S2 Fig. Colocalization of GM1a with DENV1, DENV2 and CTXB on VERO cell surface.

(A) Gm1a-Bodipy colocalized with DENV1-DiI'. (B) Gm1a-Bodipy colocalized with

DENV2-DiI'. (C) Gm1a-Bodipy colocalized with CTXB-555. (D) The control with Red and

S1 Table: Colocalization analysis of virus/CTXB and GM1a in live mammalian cells.

Mander's coefficients of colocalization and Costes P-values were determined for DENV1,

DENV2 and CTXB colocalization with GM1a.

S3 Fig. Infectivity changes of DENV1 and DENV2 by plaque assay on BHK21 cells in 
Differences in average number of deuterons exchanged (Y-axis) in DENV2 E protein:GM1a state and free DENV2 E protein state is plotted in a deuterium uptake difference plot for $\mathrm{t}=$ (X-axis). DENV2 E protein shows no protection in the presence of GM1a and shows increases in exchange in the peptide regions as labelled. Standard deviations are shaded gray and plots were generated using DynamX 3.0 software. The data is uncorrected for maximum deuterium content of $90 \%$ under experimental conditions, and unadjusted to accommodate loss in deuterons exchanged due to back-exchange (average back-exchange $\sim 15 \%$ under our HDXMS conditions).

S5 Fig. Sequence alignment of DENV1 and DENV2 E protein.

S6 Fig. Coverage maps.

1252

(A) Coverage map of E protein from dengue 2 NGC. 36 peptides spanning $63 \%$ of E protein

1253 sequence. (B) Coverage map of E protein from soluble dengue 2 NGC E protein. 107 peptides spanning $80 \%$ of E protein sequence.

1255

S7 Fig. Infectivity of DENV1 and DENV2 by plaque assay for virus labelling conditions.

(A) Plaque assay wells for DENV1. (B) Plaque assay wells for DENV2. (C) Infectivity levels comparison for (i) DENV1 and (ii) DENV2 (avg \pm SEM). P values at $\alpha=0.05$ 
(A) DENV1 in the absence of GM1a (i) trajectory on live cells, (ii) MSD curve. (B) DENV1 in the presence of GM1a (i) trajectory on live cells, (ii) MSD curve. (C) DENV2 in the absence of GM1a (i) trajectory on live cells, (ii) MSD curve. (D) DENV2 in the presence of GM1a (i) trajectory on live cells, (ii) MSD curve. (Scale bar $=2.5 \mu \mathrm{m}$ ).

S9 Fig. Diffusion coefficients of raft-marker GFP-GPI probe on live Vero cell membrane

measured by FCS.

1268

(A) Diffusion coefficient of GFP-GPI raft probe on non-treated (19/7 = curves/cells), D-PDMP

1269 treated for GM1a depletion $(29 / 10=$ curves/cells $)$ compared to when enriched with GM1a (25/10 $=$ curves/cells). (B) Respective FCS curves for (i) non-treated, (ii) D-PDMP treated cells and (iii) D-PDMP and GM1a treated cells (avg \pm SD). Red asterisk shows the average value of the distribution. measured by FCS.

(A) Diffusion coefficient of DiIC18 on non-treated (11/6 = curves/cells) versus D-PDMP treated for GM1a depletion (10/6 = curves/cells). (avg \pm SD) (B) Representative FCS curves for (i) non-treated and (ii) D-PDMP treated cells. Red asterisk shows the average value of the distribution.

S11 Fig. Properties of 2D-SPT trajectories.

Histogram of trajectory length, with information on trajectory average diffusion coefficient 
bioRxiv preprint doi: https://doi.org/10.1101/2022.01.20.477180; this version posted January 21, 2022. The copyright holder for this preprint (which was not certified by peer review) is the author/funder, who has granted bioRxiv a license to display the preprint in perpetuity. It is made available under aCC-BY 4.0 International license.

GM1a, (B) DENV1 in the presence of GM1a, (C) DENV2 in the absence of GM1a, (D)

1285 DENV2 in the presence of GM1a.

1286

1287

1288

1289

1290 

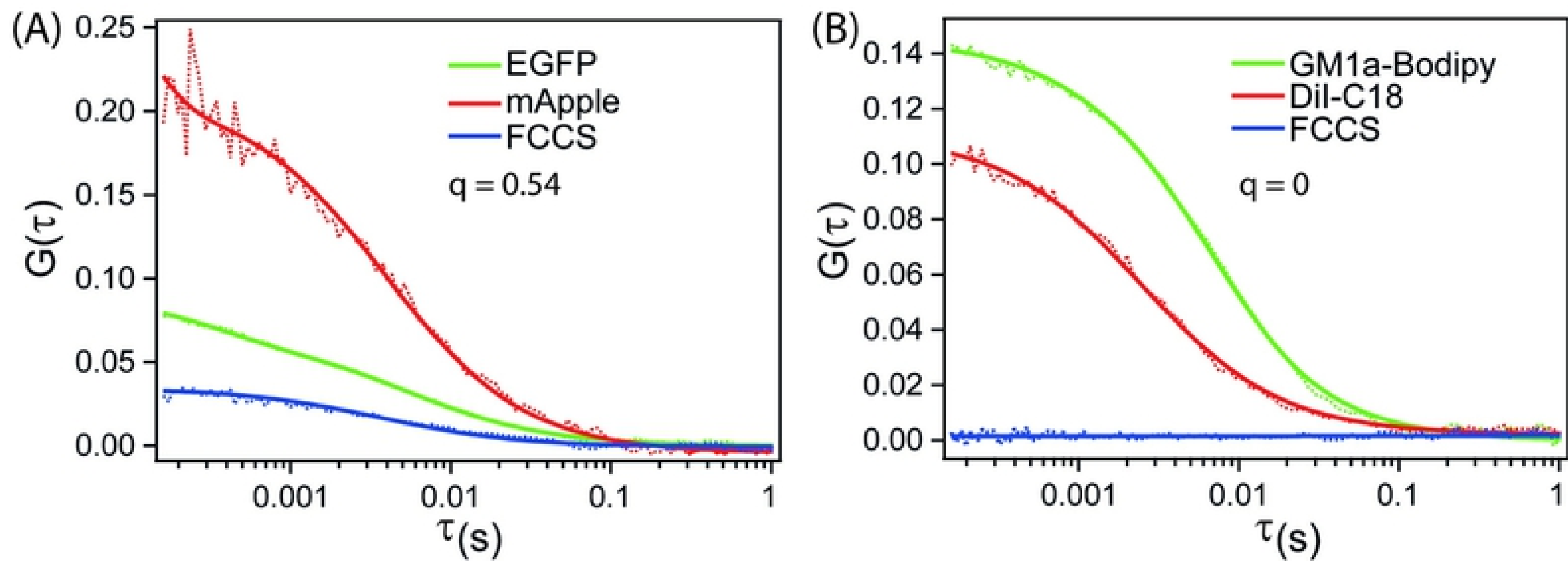

$\tau(\mathrm{s})$
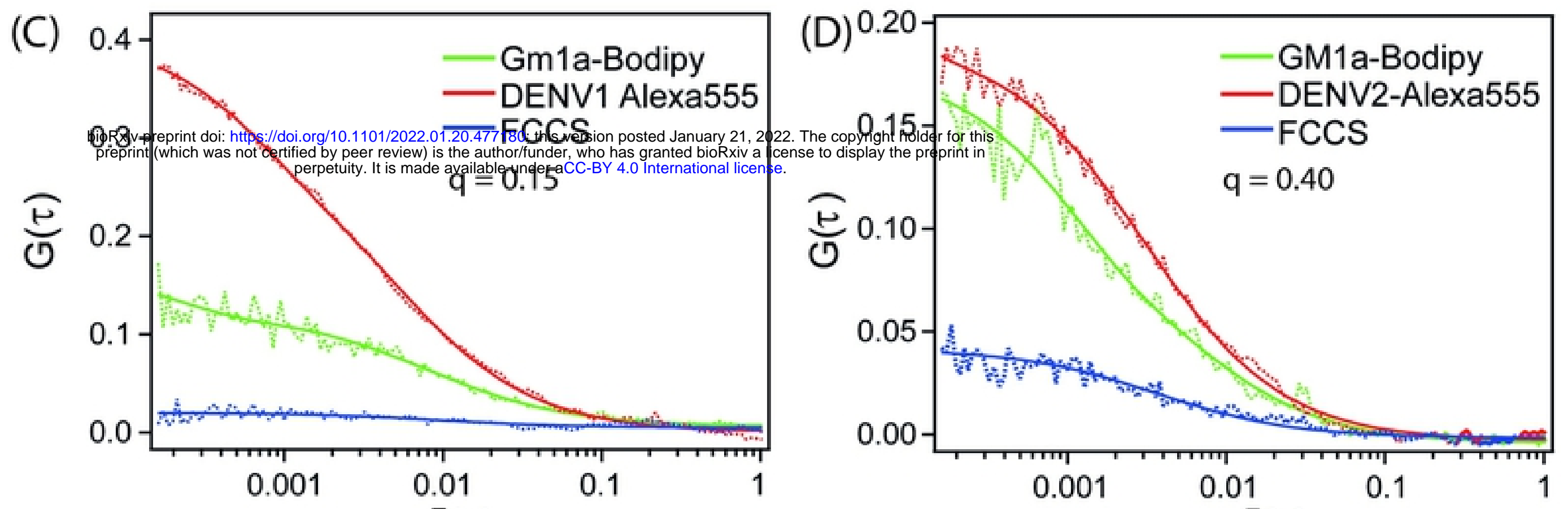

$\tau(s)$

$\tau$ (s)

(E)

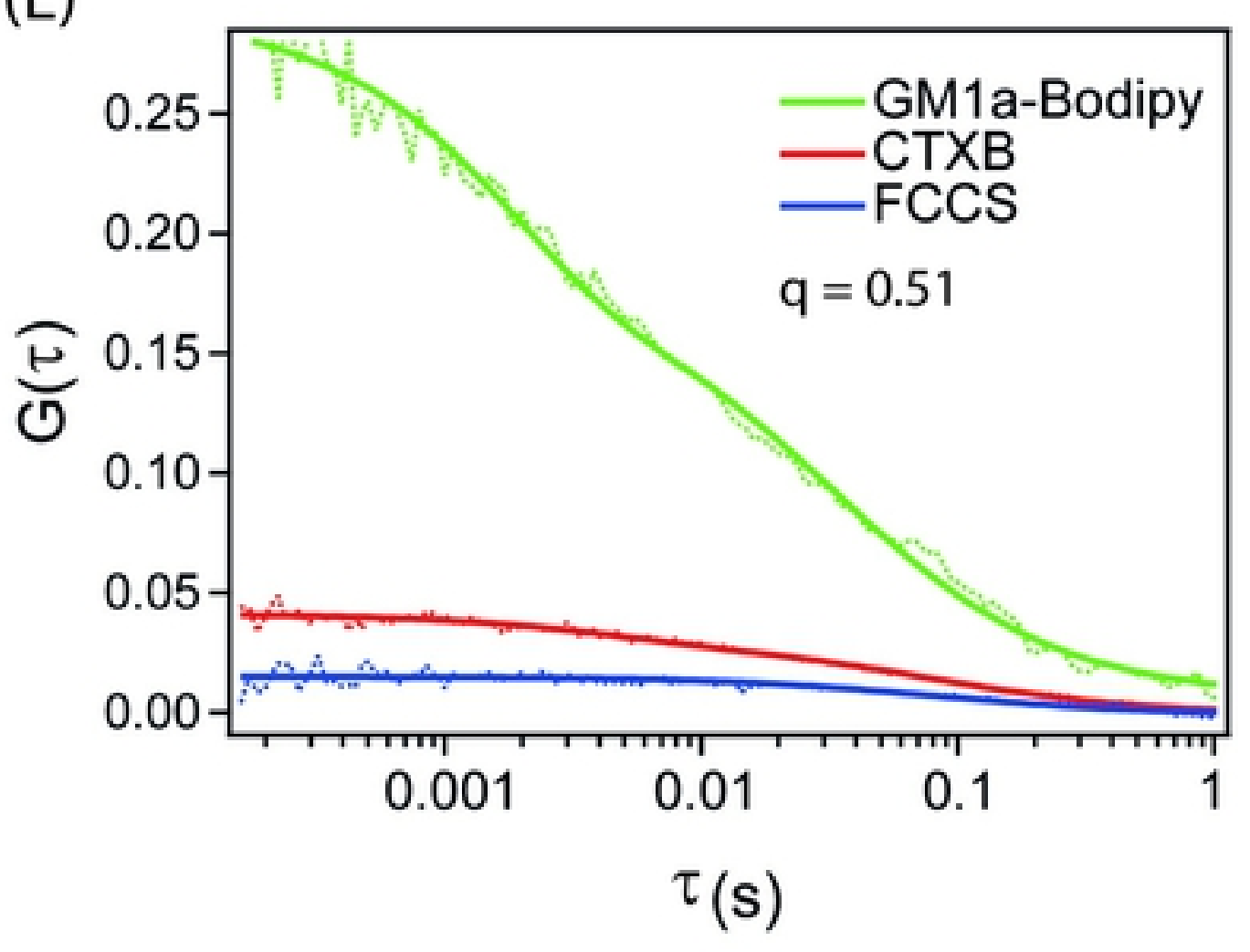

(F)

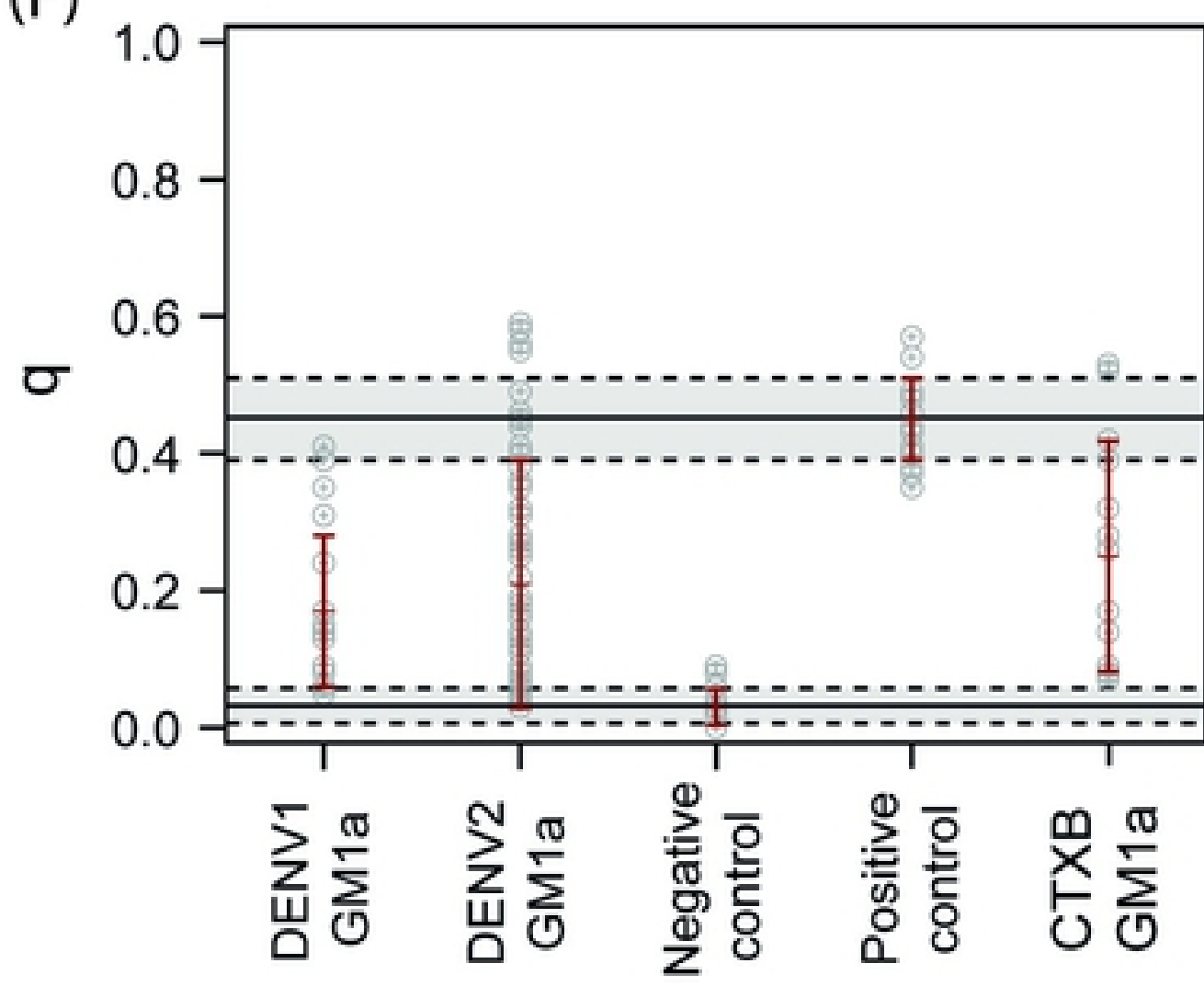

Fig 1 

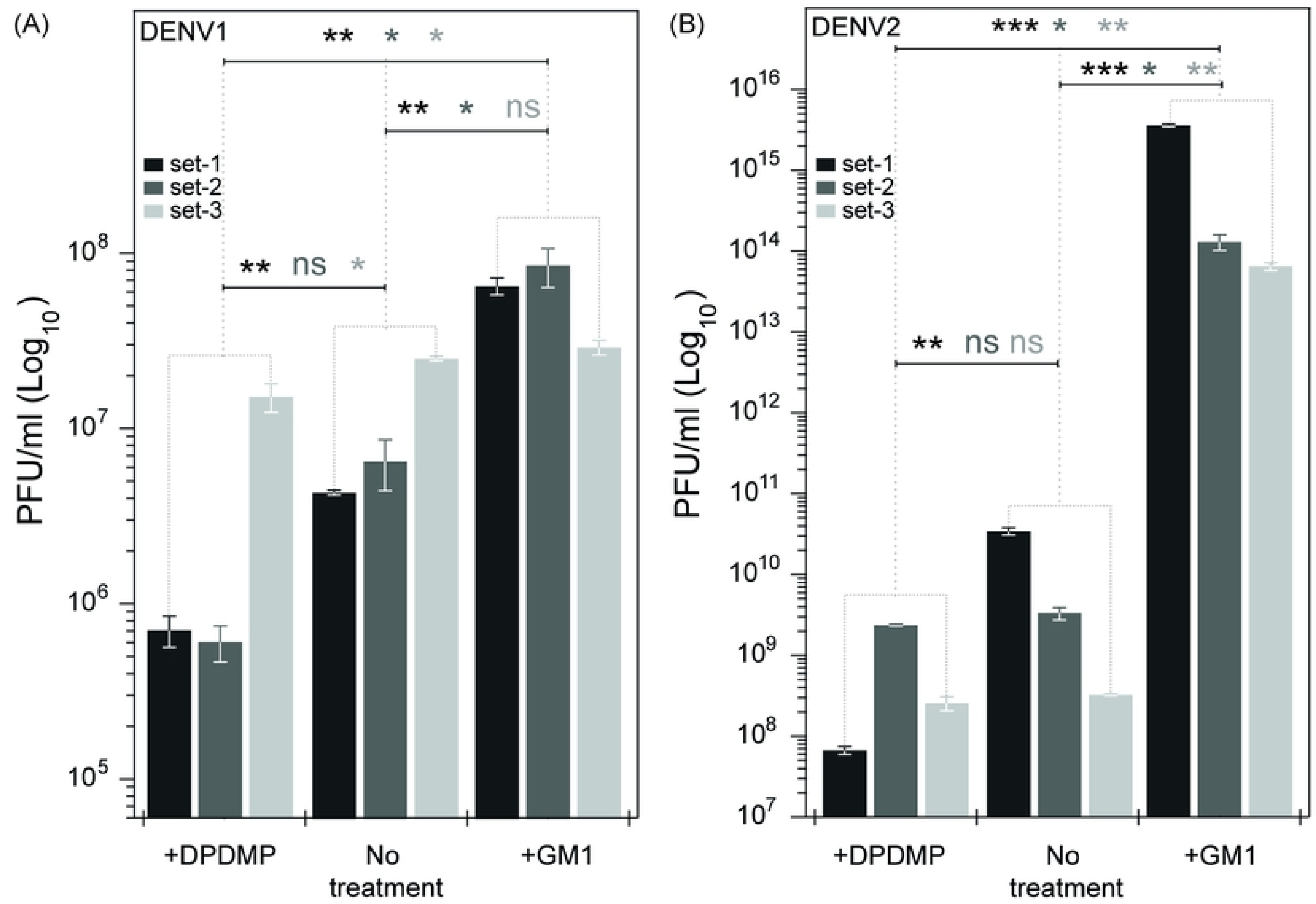

Fig 3 

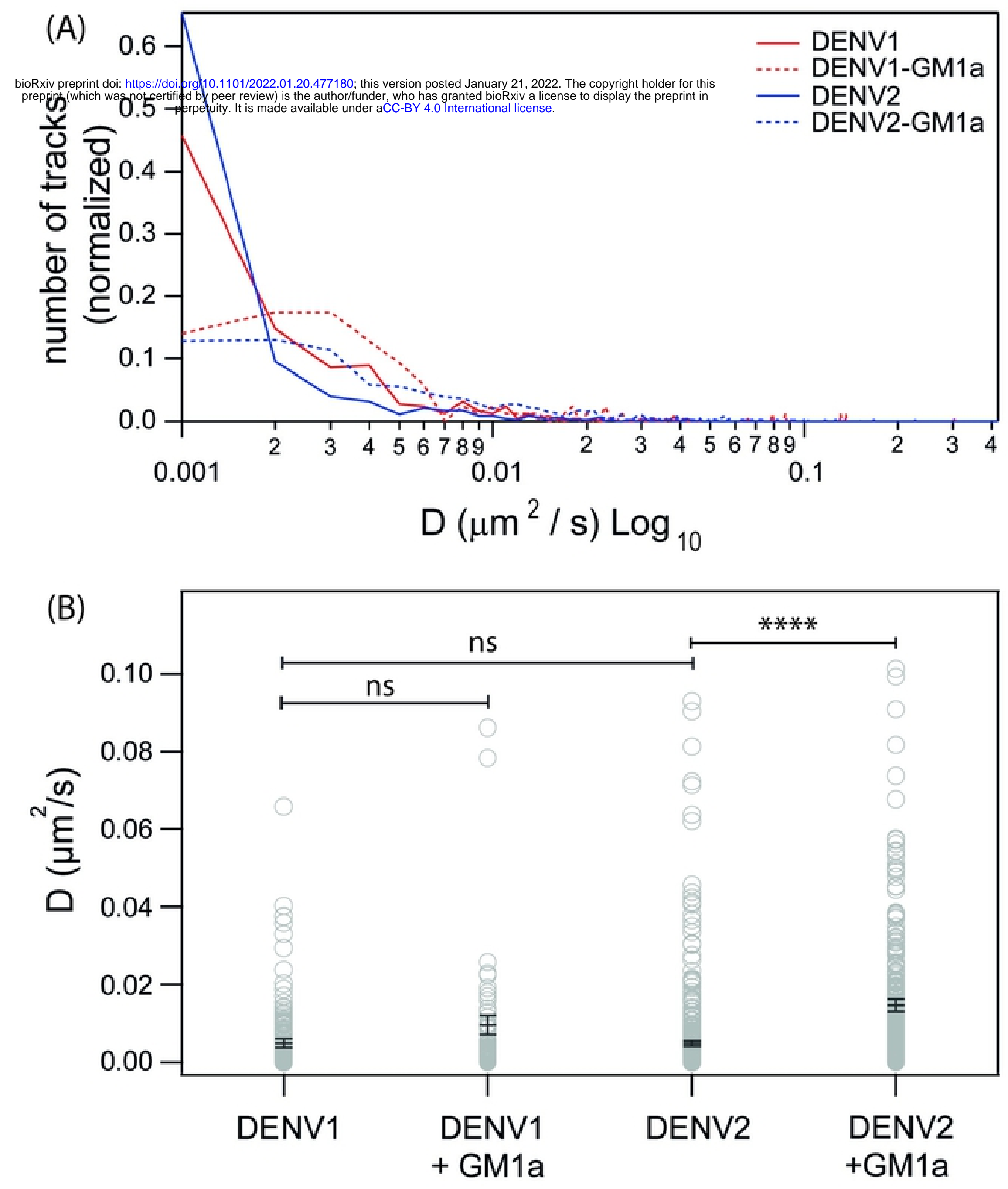

Fig 4 

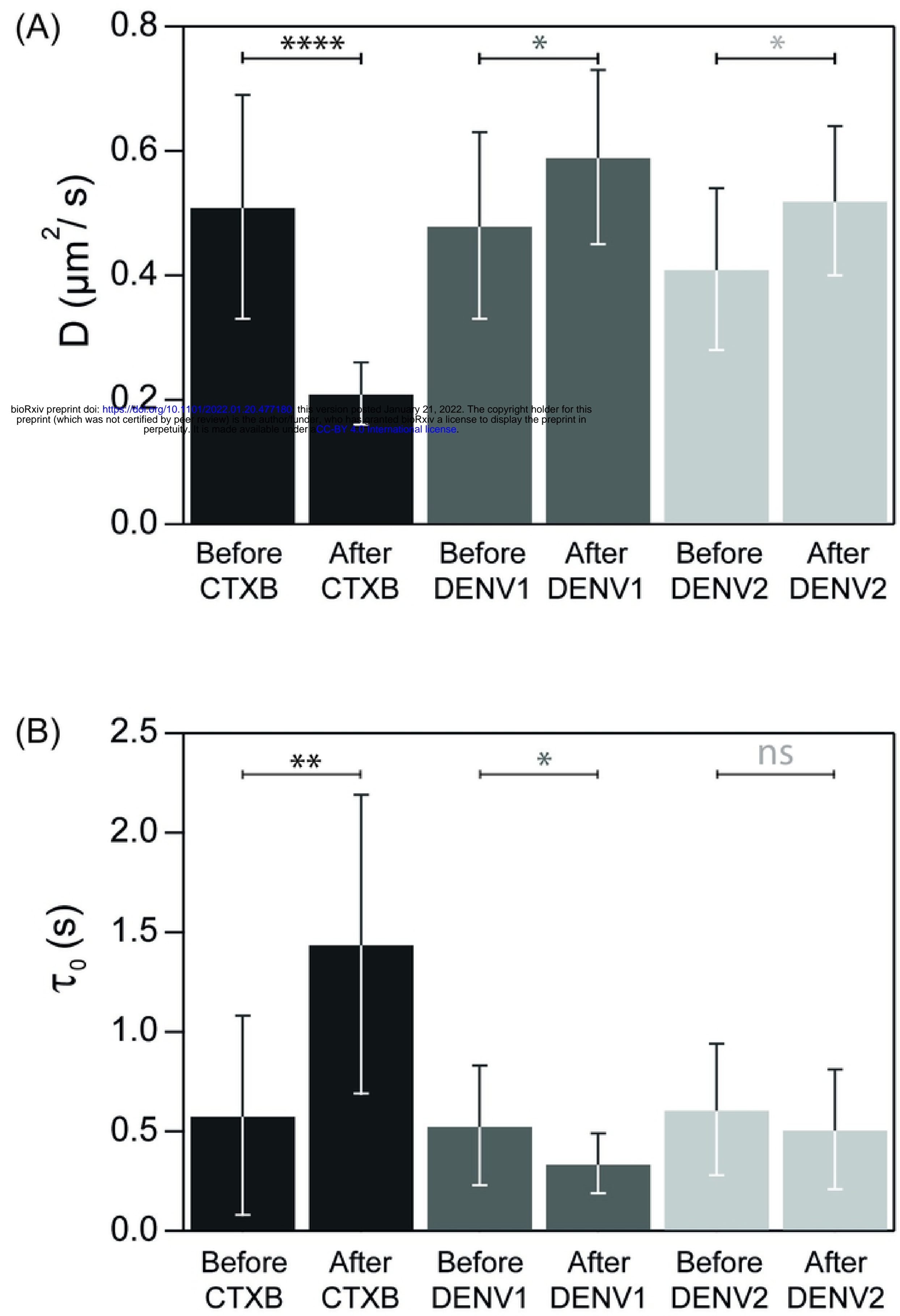

Fig 5 